\title{
Mono- and Bis- Maleimide Resins in Preimpregnated Fibres
}

\author{
Heinrich Horacek
}

A-4048 Puchenau, Am Wiesenrain 1, Austria

\begin{abstract}
Fibres are preimpregnated by solutions of mono- and bis-maleimides with comonomers. Imides alone polymerize to resins with too low energies of fracture. In the presence of Methylene dianiline or Aniline Diphenylmethylenebismaleimide reacts via Michael addition to equimolar addition products. When fibres are preimpregnated with these addition compounds alone or in combination with flame retardants, B-prepregs are obtained, which after curing show high glass temperatures and sufficient energies of fracture. 2.5 moles of Diphenylmethylene bismaleimide and $1 \mathrm{~mol}$ Methylene dianiline or 1 mole Aniline react to resins with glass temperatures of 350 and $380^{\circ} \mathrm{C}$ and energies of fracture of 75 and $100 \mathrm{~J} / \mathrm{m}^{2}$. The resins contain no carcinogen or blood harming free amines. A one pot reaction starting from Methylene dianiline and Maleic anhydride is possible and more economic. As polymerized bismaleimides possess their imide bonds in the side chain, they are strictly spoken no polyimides with imide bonds in the main chain. Diphenylmethylenebismaleimide and styrene as copolymer react to an insoluble crosslinked polymer. Fibres are preimpregnated with equimolar mixtures of 2- Bromophenylmaleimide and styrene. After curing laminates with $285^{\circ} \mathrm{C}$ glass temperature and sufficient energies of fracture are obtained. The heat resistant resins are charring polymers and display higher Limiting Oxygen Indices, when the heats of combustion are increased. Differential Scanning Calorimetry determines the temperatures and the heats of glass transition, which indicate that the glass temperature is raised, when the enthalpy is increased and the entropy reduced, which is achievable by Diphenylbismaleimide and 2Bromophenylmaleimide with their large side groups appropriate for intermolecular forces and steric hindrance.
\end{abstract}

Keywords: Thermodynamic, heat resistant, burning behaviour, brittleness, toxicity.

\section{INTRODUCTION}

Polyimides Pls are thermo resistant polymers with imide groups in the main chain. The most popular route to $\mathrm{PI}$ is based on the reaction of aromatic diamines with dianhydrides. PI is offered as thermoplastic granules, as thermoset powders or as semi finished products like preimpregnated fibres so-called prepregs, circuit boards, coil coatings, composites, varnishes or fibres for fire protective clothes. Since 1955 they are commercially available and since then many investigations documented in numerous publication have been performed [1-22]. On the one hand Pls compete with engineering and commodity plastics and on the other hand with iron and aluminium. Pls show residues between 25 to $50 \%$ and belong to the group of charring plastics. They are highly related to graphite, electric conductive polymers and organic colour pigments, which all have in common a conjugated double bond structure. They resist against heat up to $250-350^{\circ} \mathrm{C}$ and are expensive with prices of 15 to $100 € / \mathrm{kg}$. The commodity plastics polyethylene PE, polystyrene PS and the engineering plastic polyamide PA are products with prices from 1 to $4 € / \mathrm{kg}$ and with heat stabilities from 100 to $240^{\circ} \mathrm{C}$. They belong to the

*Address correspondence to this author at the A-4048 Puchenau, Am Wiesenrain 1, Austria; E-mail: aon.913086025@aon.at non charring polymers and decompose completely without residues. Table 1 allows a view on the market. In comparison with the engineering plastic Polyamide 6 and 66 with $10^{7}$ to in $2015 \mathrm{Pls}$ are niche products of still small volume. The reason for this is to be seen in their high prices, which allow only selected applications.

$\mathrm{BMI}$ are available under the brand names Matrimid from Ciba Geigy/BASF, Kerimid or Kinel from Rhone Poulenc, Compimide from Technochemie now Evonik Industries, IM-AD/BTL from Speciality Resin, Desbimide from DSM, M-S-series from Mitsui Toatsu and Homide from HOS Technik.

Other suppliers and data from the market are provided by the studies:

Kline \& Company INC: Advanced Materials Technologies high temperature Polymers 1989 Report 13

Global Bismaleimide Market by Manufactures, Regions, Type and Application, Forecast to 2021 Business Development Development Executive damandeep.k@absolutereports.com [17].

Since long PAI, PEI and PI are well established and no further developments are observed. Only the small group of BMI have experienced larger changes. 
Table 1: World Wide Consumption of Polyimides and Polybismaleimides from 1988 to 2015

\begin{tabular}{|c|c|c|c|c|c|c|c|c|}
\hline \multirow[t]{2}{*}{ Products } & \multicolumn{2}{|c|}{1988} & \multicolumn{2}{|c|}{1995} & \multicolumn{2}{|c|}{1998} & \multicolumn{2}{|c|}{2015} \\
\hline & $10^{3}$ to & $10^{6} \$$ & $10^{3}$ to & $10^{6} \$$ & $10^{3}$ to & $10^{6} \$$ & $10^{3}$ to & $10^{6} \$$ \\
\hline Polyamidimides PAI & 1.5 & 103 & 2.3 & 115 & 3.6 & 187.5 & 6 & 300 \\
\hline Poletherimides PEI & 4.5 & 49 & 8.0 & 112 & 15.8 & 170.5 & 39 & 390 \\
\hline Polyimides PI & 1.8 & 213 & 4.5 & 517.5 & 7.2 & 1158 & 20 & 2200 \\
\hline Polybismaleimides BMI & 0.5 & 21.5 & 0.7 & 35 & 0.9 & 49 & 2 & 100 \\
\hline
\end{tabular}

Bismaleimides are the reaction product of diamines with maleic anhydride. They possess two double bonds. In the presence of amines or other $\mathrm{H}$ donating compounds they perform the Michael reaction and react to the precursor resin.

1957 the patent US 2,818,405 [23] was granted to DuPont, in which liquid diamines and bismaleimides reacted to elastomers. 1968 in the patent US 3,380,964 from Rhone Poulenc [24] homo and copolymerization of $\mathrm{BMI}$ are claimed. In the same year the synthesis of polyaminobismaleimides from bismaleimides and aromatic diamines is described in Brit 1,190,718 [25]. The early market leader Rhone Poulenc withdraws Kerimid based on the carcinogenic Methylene dianiline MDA. Ciba Geigy, now BASF, develops Matrimid 5292 a 1:1 mixture of diphenylbismaleimid DPBM and diallyl bisphenol A claimed in the patent US 4,100,140 [26].

In 1990 HOS Technik enters into the market with the precursor resin Homide 250, Pyrrole 2,5dione $1,1^{\prime}$ (methylene di 4,1 phenylene) and methylene bis(benzene amine) CAS 26140-67-0 with reduced amount of free MDA. The procedure is described and claimed in WO 97/33933 [27].

Toxicity and price largely depend on the aromatic diamine applied in the synthesis of BMI as well as on the amine, which serves as comonomer in the Michael reaction.

Table 2 shows possible candidates as alternatives for MDA: 5 (6) Amino 4'aminophenyl -1,3 trimethylindane, 2, 5 Bis(4-aminophenylthio) thiadiazole BDT [28-30], 2(4-5 Aminophenylthio) 4(4-aminophenyloxo) thiazol BT, Tris (3 -aminophenyl) phosphine oxid TAP, 4, 4 Bis (4 -aminophenoxyphenyl)sulfone p-BAPS and 4, 4 Bis (3-aminophenyloxyphenyl)sulfone m.BAPS and 2, 5 Bis(4-aminophenylthiophenyl)sulfone BDS.

Aniline, which reacts with formaldehyde to Methylenedianiline MDA, is the cheapest amine in the list of diamines in Table 2, but as mono amine aniline can be only applied in the Michael reaction. MDA and Naphthene diamine NDA are key products for polyurethanes and are available in large quantities. Also 5(6) Amino 1- (4'aminophenyl) 1, 3 trimethylindane DAPI, a reaction product of two molecules alpha Methylstyrene, is moderate in price. $\mathrm{m}$ - Aminophenol and m-Aminobenzoic hydrazide are building parts in commercial products.

Diamines can be used as reactants for the synthesis of bismaleimides and or as ingredients for the Michael reaction. Mono amines can only react in the synthesis of mono maleimides or in the Michael reaction. Mono maleimides and styrene polymerize to heat resistant styrene maleimide polymers. When the same diamine is used in the synthesis of bismaleimide and in the Michael reaction, the two stage reaction can be performed in a one pot reaction starting from one mole diamine and two moles maleic anhydride for the bismaleimide reaction followed by the Michael reaction between bismaleimide and diamine to the BMI resin.

Many bismaleimides BMI, which are based on MDA and other diamines such as those given in Table $\mathbf{2}$ are described in the literature $[3,33]$. Their data as far as available are represented in Table $\mathbf{3}$ and $\mathbf{3 a}$ : Their formulas, molecular weights $\mathrm{MW}$, heats of formation $\mathrm{Hf}$, heats of melting and polymerization $\mathrm{hm} / \mathrm{hpol}$ as well as combustion and decomposition hcomb and hdec, the temperatures of melting, of polymerization, of glass transition and decomposition $\mathrm{Tm}, \mathrm{Tpol}, \mathrm{Tg}$ and Tdec and the amount of residue Rdec are summarized.

The data for the heats of formation $\mathrm{Hf}$ and of combustion hcomb are calculated according to van Krevelen [42,43].

The heats of decomposition hdec as well as the residuals after degradation Rdec result from balances of weights and heats.

The most important measure for the achieved thermo resistance is to be seen in the glass transition 
Table 2: Aromatic Amines their Abbreviation, their CAS and Formula

\begin{tabular}{|c|c|c|c|c|}
\hline Product & Abbreviation & CAS & Formula & $\operatorname{Tf}\left({ }^{\circ} \mathrm{C}\right)$ \\
\hline Aniline & A & $62-53-3$ & $\mathrm{C}_{6} \mathrm{H}_{7} \mathrm{~N}$ & -6 \\
\hline Methylene dianiline & MDA & $101-77-9$ & $\mathrm{C}_{13} \mathrm{H}_{14} \mathrm{~N}_{2}$ & 80 \\
\hline 5 (6) Amino 4'aminophenyl- 1,3 trimethylindane & DAPI & $62929-12.6$ & $\mathrm{C}_{18} \mathrm{H}_{22} \mathrm{~N}_{2}$ & - \\
\hline 2, 5 Bis(4-aminophenylthio)thiadiazol & BDT & & $\mathrm{C}_{14} \mathrm{H}_{12} \mathrm{~N}_{4} \mathrm{~S}_{3}$ & 253 \\
\hline $\begin{array}{l}2 \text { (4-aminophenylthio) 4(4- } \\
\text { aminophenyloxo)thiazol }\end{array}$ & BT & & $\mathrm{C}_{15} \mathrm{H}_{14} \mathrm{~N}_{3} \mathrm{~S}_{2} \mathrm{O}$ & 175 \\
\hline 4,4 Bis(4-aminophenylthiophenyl)sulfone & BDS & & $\mathrm{C}_{24} \mathrm{H}_{20} \mathrm{~N}_{2} \mathrm{~S}_{3} \mathrm{O}$ & 250 \\
\hline 4,4 Bis(3- aminophenoxyphenyl)sulfone & m-BAPS & & $\mathrm{C}_{24} \mathrm{H}_{20} \mathrm{~N}_{2} \mathrm{O}_{4} \mathrm{~S}$ & - \\
\hline 4,4 Bis(4-aminophenoxyphenyl)sulfone & p-BAPS & $13080-89-2$ & $\mathrm{C}_{24} \mathrm{H}_{20} \mathrm{~N}_{2} \mathrm{O}_{4} \mathrm{~S}$ & 188 \\
\hline Tris(3-aminophenyl)phosphine oxide & TAP & $36357-49-0$ & $\mathrm{C}_{18} \mathrm{H}_{18} \mathrm{~N}_{3} \mathrm{O}_{4} \mathrm{P}$ & 260 \\
\hline m- Aminophenol & $\mathrm{m}-\mathrm{AP}$ & $591-27-5$ & $\mathrm{C}_{6} \mathrm{H}_{7} \mathrm{NO}$ & 122 \\
\hline m- Aminobenzoic hydrazide & $\mathrm{m}-\mathrm{AH}$ & $5351-17-7$ & $\mathrm{C}_{7} \mathrm{H}_{9} \mathrm{~N}_{3} \mathrm{O}$ & 105 \\
\hline 1,5 Diaminonaphthalene & NDA & $2243-62-1$ & $\mathrm{C}_{10} \mathrm{H}_{10} \mathrm{~N}_{2}$ & 186 \\
\hline
\end{tabular}

Table 3: Bismaleimides Based on Different Diamines

\begin{tabular}{|c|c|c|c|c|}
\hline Diamine & MDA & DAPI & BDS & TAP \\
\hline Formula & $\mathrm{C}_{21} \mathrm{H}_{14} \mathrm{~N}_{2} \mathrm{O} 4$ & $\mathrm{C}_{26} \mathrm{H}_{22} \mathrm{~N}_{2} \mathrm{O}_{4}$ & $\mathrm{C}_{32} \mathrm{H}_{22} \mathrm{~N}_{2} \mathrm{~S}_{3} \mathrm{O}_{6}$ & $\mathrm{C}_{26} \mathrm{H}_{18} \mathrm{~N}_{3} \mathrm{O}_{5} \mathrm{P}$ \\
\hline MW g/mole & 358 & 426 & 626 & 483 \\
\hline Hf kJ/mole & $-477,5$ & -545 & -316 & -831 \\
\hline hm/hpol kJ/g & $0.09 /-0.27$ & /-0.09 & $/-0.13$ & $1-0.22$ \\
\hline $\mathrm{Tm} / \mathrm{Tpol} / \mathrm{Tg}^{\circ} \mathrm{C}$ & $155 / 240 / 435$ & 95/203/- & $140 /-/-$ & $95 / 195 / 320$ \\
\hline hcomb kJ/g & -27.3 & -30.1 & -26.1 & -20.4 \\
\hline $\operatorname{Tdec}{ }^{\circ} \mathrm{C}$ & 490 & 450 & 439 & 460 \\
\hline hdec kJ/g & 0.41 & 0.90 & 0.19 & 0.86 \\
\hline Rdec \% & 45 & 11 & 15 & 25 \\
\hline CAS/ Lit. & $13676-54-5$ & 3)34) & 35)36) 37) & 31)32)33) \\
\hline
\end{tabular}

\section{Table 3a:}

\begin{tabular}{|c|c|c|c|c|}
\hline Formula & $\mathrm{C}_{22} \mathrm{H}_{12} \mathrm{~N}_{4} \mathrm{~S}_{3} \mathrm{O}_{4}$ & $\mathrm{C}_{32} \mathrm{H}_{20} \mathrm{~N}_{2} \mathrm{O}_{8} \mathrm{~S}$ & $\mathrm{C}_{32} \mathrm{H}_{20} \mathrm{~N}_{2} \mathrm{O}_{8} \mathrm{~S}$ & $\mathrm{C}_{23} \mathrm{H}_{13} \mathrm{~N}_{3} \mathrm{~S}_{2} \mathrm{O}_{5}$ \\
\hline $\mathrm{Hf} \mathrm{kJ/mole}$ & 46 & -959 & -959 & -337 \\
\hline $\mathrm{hpol} \mathrm{kJ/g}$ & -0.19 & -0.16 & -0.19 & -0.17 \\
\hline hcomb kJ/g & -23.0 & -25.0 & $-25,0$ & -23.8 \\
\hline $\operatorname{Tdec}{ }^{\circ} \mathrm{C}$ & 430 & 460 & 430 & 450 \\
\hline hdec kJ/g & 0.27 & 1.56 & 1.56 & 0.88 \\
\hline Rdec \% & 16 & 30 & 18 & 8 \\
\hline
\end{tabular}


temperature $\mathrm{Tg}$ and the temperature of decomposition Tdec. As the temperatures of degradation for heat resistant polymers do not differ very much and lie at about $450^{\circ} \mathrm{C}$, the most important property remains $\mathrm{Tg}$. Bismaleimide BMI based on MDA has a high glass temperature of $435^{\circ} \mathrm{C}$. BMl synthesized from Tris (3aminophenyl) phosphine oxide TAP described by Varma [29-33] exerts a glass temperature of $320^{\circ} \mathrm{C}$. From the mentioned BMls the glass temperatures are not available. Under the assumption that a high Tm will lead to a high $\mathrm{Tg}$ bismaleimides based on2,5 Bis(aminophenylthio)thiadiazol bismaleimide BDT with the highest $\mathrm{Tm}$ of $265^{\circ} \mathrm{C}$ followed by p-BAPS $4,4^{\prime}$ bis (4-aminophenoxyphenyl)sulfone with $\mathrm{Tm}=250^{\circ} \mathrm{C}$ and 2 (4-Aminophenylthio) 4(4-aminophenyloxo) thiazol bismaleimide BT with $\mathrm{Tm}=205^{\circ} \mathrm{C}$ are those, which promise high $\mathrm{Tg}$. Interesting is the fact that 1-(4aminophenyl)-1, 3 trimethylindane bismaleimide DAPI evolves about half the heat of polymerization. With Tm $=90^{\circ} \mathrm{C}$ m-BAPS, though nearly related to $p$-BAPS, has the lowest temperature of fusion. The observed or expected advantages in properties seem not enough to justify a switch over from MDA to a substitute. Therefore a critical look is thrown on BMI based on MDA with the aim of reduction of toxicity and costs of manufacture: The precursor DPBM/MDA 2.5/1 molar ratio with very low MDA free content is produced in a one pot reaction starting from MDA and MSA or the cheap aniline is integrated into the prepolymer DPBM/A 2.5/1 instead of MDA. Equimolar mixtures of Styrene and 2- Bromophenylmaleimide applied on fibres are prepregs, which cure to polymers with high glass temperature and sufficient fracture energy.

\section{EXPERIMENTAL}

In Table 4 the ingredients used and their providers were summarized.

For the production of DPBM from MDA and maleic anhydride three different procedures were described:

1. Acetic anhydride dehydration in DMF or acetone US 3,127,414 [38]

2. Closed loop thermal dehydration in toluene and dichloromethane Daman Global Bismaleimide Market by Manufacturers (2017) [17]

3. Azeotropic distillation in toluene WO $97 / 47597$ $[39,40]$

Table 4: Chemicals used for the Production of BMI Precursor Resins

\begin{tabular}{|c|c|c|}
\hline Chemical & Provider & CAS No \\
\hline 4,4' Bismaleinimidodiphenylmethylene DPBM & HOS Technik & $13676-54-5$ \\
\hline Dimethylformamide DMF & DuPont & $68-12-2$ \\
\hline Maleic acid anhydride MSA & DSM & $108-31-6$ \\
\hline Diaminodiphenylmethane MDA & BASF & $9063-71-2$ \\
\hline Acetic acid anhydride & Augusta Laborbedarf & $108-24-7$ \\
\hline Methane sulfonic acid & elf atochem & $75-75-2$ \\
\hline N-Xylylmaleimide Xylyl & Chemie Linz & $1206-49-1$ \\
\hline N-Phenylmaleimide Phenyl & Chemie Linz & $941.69-5$ \\
\hline 2-Bromophenylmaleimide BrPhenyl & Chemie Linz & \\
\hline Tribromphenylmaleimide TBrP & Chemie Linz & $59789-51-4$ \\
\hline Ethylene bis tetrabromophthalimide ETBr & Saytex BT93 & $32588-76-4$ \\
\hline Bicyclopentaerythritol phosphate BCPP & Great Lakes Chemical NH 1197 & \\
\hline Dicyandiamide and Melamine DCDA/M & BASF & $461-58-5 / 108-78-1$ \\
\hline Melamine polyphosphate MPP & cfb Budenheim Budit 3141 & $56386-64-2$ \\
\hline Glass tissue US $2116100 \mathrm{~g} / \mathrm{m}^{2}$ & Tissa Comp. & \\
\hline Aniline A & BASF & $62-53-3$ \\
\hline Di-tert butylperoxid & Peroxidchemie & $110-05-4$ \\
\hline Azoisobutyronitril AiBN & Mainchem Co. & $78-67-1$ \\
\hline Toluene & INEOS Köln GmbH & $108-88-3$ \\
\hline
\end{tabular}


The One Pot Process in $40 \%$ Solution W097/3393 A1 [27]

98g MSA were dissolved in 200g DMF. A solution of $99 \mathrm{~g}$ MDA in $125 \mathrm{~g}$ DMF was added. The mixture was stirred for 2 hours at RT. In this time MSA and MDA reacted to the amidoacid. Then $0.5 \mathrm{~g}$ methane sulfonic acid was added and the temperature was raised to $100^{\circ} \mathrm{C}$ and a vacuum of $270 \mathrm{mbar}$ was applied. A distillate comprising $17 \%$ water and $83 \%$ DMF evaporated. When $18 \mathrm{~g}$ water was removed, imidization was finished and the temperature was reduced to $60^{\circ} \mathrm{C}$. A solution of $39 \mathrm{~g}$ MDA in $95 \mathrm{~g}$ DMF was added. When the viscosity had risen from 5 to $16 \mathrm{cSt}$ at $25^{\circ} \mathrm{C}$, the solution was cooled to RT. The content was stirred for $1 \mathrm{~h}$ and then precipitated in $1000 \mathrm{~g}$ water. The yellow precipitate was filtered, carefully washed with MSA acidic water followed by washing with distilled water. After filtration a yellow cake was obtained, which was dried at $70^{\circ} \mathrm{C}$ under vacuum. The yield was $213 \mathrm{~g}$ or $98 \%$ of theory. The free MDA content was less $0.1 \%$. Discoloration by formation of aniline black was not observed.

\section{Preparation of BMI Resin 2.5m DPBM and $1 \mathrm{~m}$ MDA with a Free MDA Content of Less than $0.1 \%$ [27]}

In a first step DPBM was synthesized [31].

In a second step the Michael reaction took place: $2.5 \mathrm{~m}$ DPBM and 1m MDA to the precursor in $40 \% /$ $55 \%$ solution at $60^{\circ} \mathrm{C}$.

A 4 I vessel was charged with $1256 / 942$ D DMF and $687 / 945 \mathrm{~g}$ DPBM. The vessel was stirred and heated to $40^{\circ} \mathrm{C}$. When all DPBM was solved $151 / 207 \mathrm{~g}$ MDA was added. The whole vessel was floated with $\mathrm{N}_{2}$. The content was heated to $60^{\circ} \mathrm{C}$ and kept at that temperature for $3 \mathrm{~h}$, until the viscosity had increased 5 to $16 \mathrm{cSt}(40 \%)$ or 15 to $60 \mathrm{cSt}(55 \%)$ and the IR band for primary amine band at $3338 \mathrm{~cm}^{-1}$ had disappeared. Then the vessel was cooled to $30^{\circ} \mathrm{C}$, and the content was precipitated into MSA acidic cold water $(\mathrm{pH}=2-3)$. After filtration the retained cake was washed with MSA acid water $(\mathrm{pH}=2-3)$ followed by washing with distilled water. The yield amounted $98 \%$ and the content of MDA free was less $0.1 \%$

Preparation of BMI Resin 2.5m DPBM and $1 \mathrm{~m}$ Aniline A with a Free A Content of Less than $0.1 \%$

The reaction was performed in analogy to the reaction of $\mathrm{N}$-phenylmaleimide with aniline [38].
A 4 I vessel was charged with $852.5 \mathrm{~g}$ DMF and $945 \mathrm{~g}$ DPBM. The vessel was stirred and heated to $40^{\circ} \mathrm{C}$. When all DPBM was solved, $98 \mathrm{~g} \mathrm{~A}$ were charged. The whole vessel was floated with $\mathrm{N}_{2}$. The content was heated to $60^{\circ} \mathrm{C}$ and kept at that temperature for about $3 \mathrm{~h}$, until the viscosity reached $14 \mathrm{cSt}$ and the primary amine band had disappeared. Then the vessel was cooled to $30^{\circ} \mathrm{C}$. The content was precipitated into MSA acidic water cold water. After filtration the cake was washed with MSA acid water $(\mathrm{pH}=2-3)$ followed by distilled water. The yield amounted $1022 \mathrm{~g}$ or $98 \%$ of theory and the content of free A was less $0.1 \%$.

\section{Preparation of Copolymers from Styrene with Phenylmaleimide, Xylylmaleimide, 2-Brom Phenylmaleimide and DPBM}

A stirred vessel was loaded with $0.1 \mathrm{~mole}$ styrene, 0.1 mole maleimide and $400 \mathrm{ml}$ toluene and heated to reflux. Then $0.2 \% \mathrm{Di}$ tert- butylperoxide and $0.2 \% \mathrm{AiBN}$ were added. After $2 \mathrm{~h}$ reflux at $110^{\circ} \mathrm{C}$ the solvent was eliminated in a Rotavapor. The residue was washed with acetone and dried at $100^{\circ} \mathrm{C}$ under vacuum for $6 \mathrm{~h}$.

Preparation of B Prepregs Comprising BMI Resins with $2.5 \mathrm{~m}$ DPBM and $1 \mathrm{~m}$ MDA or $1 \mathrm{~m}$ A or Styrene-2Bromophenylmaleimide Resin as well as FRs in Addition in a Tube Reactor Combined with an Impregnation Device for Glass Tissues

The reactor consisted of a stirred $10 \mathrm{l}$ vessel with an outlet on the bottom equipped with a pump leading into a copper tube with static mixing elements. A KDM small dosage balance Engelhardt dowitec fed the vessel continuously with a powder mixture comprising $82 \%$ DPBM and $18 \%$ MDA or $90.6 \%$ DPBM and $9.4 \% A$ and $0-20 \%$ FR and an inlet provided DMF for a $55 \%$ solution. The tube with $1.3 \mathrm{~cm}$ diameter and a length of $50 \mathrm{~m}$ had a volume of 6.6 I. For the sake of space saving the tube was wounded and placed in a water bath. On one end of the tube was the pump for dosage and on the other end a nozzle with a slit with $1 \mathrm{~m}$ breadth and a variable width of about $1.3 \mathrm{~mm}$. Through the nozzle the solution entered a dipping bath tub. The glass tissue was continuously transported into the bath filled with solution. There it was converted over a diverting roller. The loaded tissue left the bath and entered an IR drying funnel of $1 \mathrm{~m}$ length. In the funnel it was diverted and passed once more the bath. After twice dipping it entered again the drying funnel and was once more diverted. The temperature in the drying funnel was $130^{\circ} \mathrm{C}$ and the drying distance after the last dip was $2 * 1 \mathrm{~m}$. The impregnated tissue left the dryer in the $\mathrm{B}$ state. 
Prepregs with $50 \%$ resin and $50 \%$ glass content were produced from the glass tissue US 2116 (Tissa Comp.) with a basic weight of $100 \mathrm{~g} / \mathrm{m}^{2}$.

The monomers for the resins 1,2 and 3 were applied as $55 \%$ solutions with a densities at $60^{\circ} \mathrm{C}$ of $1.05 \mathrm{~g} / \mathrm{cm}^{3}$.

$\begin{array}{ccc}\text { Resin } 1 & \text { Resin } 2 & \text { Resin } 3 \\ 450 \mathrm{~g} \text { DPBM } & 498 \mathrm{~g} \mathrm{DPBM} & \begin{array}{c}389.3 \mathrm{~g} \mathrm{2}- \\ \text { Bromophenylmaleimide }\end{array} \\ 100 \mathrm{~g} \mathrm{MDA} & 52 \mathrm{~g} \mathrm{~A} & \begin{array}{c}\text { 160.7g Styrene }+0.6 \mathrm{~g} \\ \text { Benzoylperoxide }\end{array} \\ \begin{array}{c}\text { 450g DMF+5, 10, } \\ 15,20 \% \text { FR }\end{array} & 450 \mathrm{~g} \mathrm{DMF} & 450 \mathrm{~g} \mathrm{DMF}\end{array}$

In addition flame retardants FR were applied: the halogen flame retardants Trisbromophenyl maleimide TBP, Ethylene bis tetrabromophthalimide EBTBP as well as the halogene free flame retardants Bicyclopentaerythritol phosphate BCPP, equimolar mixture of dicyandiamide and melamine DCDA/M and melamine polyphosphate MPP.

\section{Manufacture of Laminates from B-Prepregs}

Laminates with $1.6 \mathrm{~mm}$ thickness, which are appropriate samples for the UL 94 test, were produced on a Langzauner 220T vacuum press. 14 layers of B stage prepregs were piled and put into the press. Then the press was closed under a pressure of $15 \mathrm{bar}$. Within 30 minutes the press was heated to $180^{\circ} \mathrm{C}$ and kept at that temperature for 1 hour. In every case about $5 \%$ flux of resin was detected. Then the laminate with $1.6 \mathrm{~mm}$ thickness and about $45 \%$ resin content was taken out and cured at $200^{\circ} \mathrm{C}$ for 48 hours for optimizing the properties.

\section{Characterization of Products}

Thermogravimetric Analysis TGA, Thermomechanic Analysis TMA as well as Differential Scanning Calorimetric DSC measurements were performed on a Mettler Toledo TMA/SDTA 840 with TGA/SDTA 851 Modul. Chemicals or extruded samples were placed in aluminium oxide crucibles of $900 \mu \mathrm{l}$ volume (ME 511119 , 960) with $12 \mathrm{~mm}$ diameter covered by punctured lids. The TGA measurements took place under nitrogen or air with $80 \mathrm{ml} / \mathrm{min}$ at a heating rate of $5-50 \mathrm{~K} / \mathrm{min}$. The TMA measurements were performed in aluminium oxide crucibles with $7 \mathrm{~mm}$ diameter and $4.6 \mathrm{~mm}$ height covered by $6 \mathrm{~mm}$ diameter lids in air at a heating rate of $5-50 \mathrm{~K} / \mathrm{min}$ under nitrogen. The heats of combustion hcomb were measured in a calorimeter according to DIN 51900 Teil 2 (1977) Heizwertbestimmung and calculated. In DSC measurements the chemicals were heated at different heating rates under nitrogen. In this manner the heats and temperatures of fusion hf and Tf as well as those of decomposition Tdec and hdec were determined. TGA measurements under air or nitrogen allowed the determination of residues R.MDA free was determined by gas chromatography Werkvoorschrift Nr. 3002WV-0192 BASF Antwerpen N.V. (1992). The kinematic viscosity was measured in an Ubbelohde viscosimeter according DIN 51562. Fourier- transform absorption spectroscopy was performed on a Bruker IFS 45 spectrometer with the following conditions $4000-400 \mathrm{~cm}^{-1}$ spectral band, liquid state in couvettes.

\section{RESULTS}

\section{The Reaction of 2.5 moles DPBM with 1 mole MDA to BMI Resin}

DPBM and MDA were dissolved in DMF in 40 and $55 \%$ concentration. The reaction was followed at

Table 5: Production of B-Prepreg without and with FR at $60^{\circ} \mathrm{C}$ Temperature in a Tube Reactor: Output $\mathrm{I} / \mathrm{h}$, Reaction Time $h$, Speed of the Tissue $\mathrm{m} / \mathrm{h}$ and Drying Time $\mathrm{h}$ at $130^{\circ} \mathrm{C}$

\begin{tabular}{|c|c|c|c|c|c|c|}
\hline Output I/h & Resin $1 / 2 / 3 \mathrm{~g} / \mathrm{h}$ & FR $g / h$ & $\mathrm{DMF} / \mathrm{DMF}+\mathrm{A} / \mathrm{DMF}+\mathrm{S} \mathrm{g} / \mathrm{h}$ & reaction time $h$ & tissue speed $\mathrm{m} / \mathrm{h}$ & drying time $h$ \\
\hline 1 & $550 / 498 / 389$ & & $450 / 502 / 611$ & 6.6 & 5 & 0.4 \\
\hline 1.5 . & $825 / 747 / 583$ & & $675 / 753 / 916.5$ & 4.4 & 7.5 & 0.27 \\
\hline 2 & $1100 /$ & & $900 /$ & 3.3 & 10 & 0.2 \\
\hline 1.5 & $804.4 /$ & 20.6 & $675 / \mathrm{TBrP} 2.5 \%$ & & & \\
\hline 1.5 & $783.75 /$ & 41.25 & $\begin{array}{c}\text { 675/ TBrP, ETBr, BCPP, } \\
\text { DCDA/M, MPP 5\% }\end{array}$ & & & \\
\hline 1.5 & $742.5 /$ & 82.5 & $\begin{array}{c}\text { 675/ TBrP, ETBr, BCPP. } \\
\text { DCDA/M. MPP 10\% }\end{array}$ & & & \\
\hline 1.5 & $701.3 /$ & 123.7 & $675 / \operatorname{TBrP} 15 \%$ & & & \\
\hline
\end{tabular}


viscosity versus MDA free

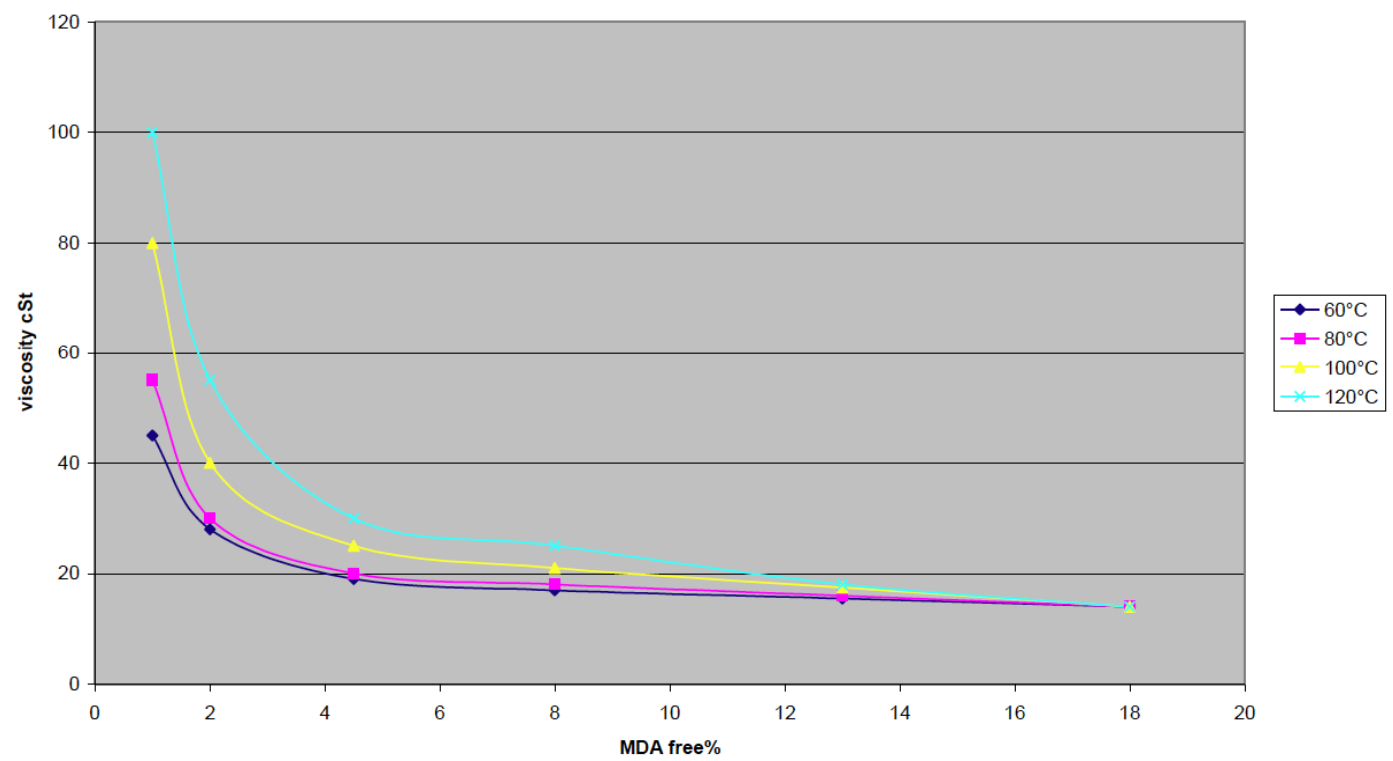

Figure 1: Viscosity cSt versus w\% MDA free (solid product) in a $55 \%$ solution in DMF.

temperatures between 40 and $120^{\circ} \mathrm{C}$ by the content of free MDA and increase in viscosity as given in Figure 1 showing the hyperbolic curves for the free MDA calculated for solid in order to eliminate the influence of concentration and the corresponding viscosity for a $55 \%$ solution.

In Figure 1 the curves were of hyperbolic shape, indicating that the product MDA free ${ }^{*} v$ was constant. In Table 6 the viscosities for $40 \%$ and $55 \%$ solution were listed in dependence of the conversion $\mathrm{c}$.

Equilibrium was observed for the Michael addition. At each temperature the reaction stopped at a definite amount of MDA free. Therefore the equilibrium with the constant Ke was set up in equation 1: 1-c moles MDA and 2.5-c moles DPBM were in equilibrium with $c$ moles MDADPBM at the conversion $\mathrm{c}$.

$\mathrm{Ke}=\mathrm{MDADPBM} /\left(\mathrm{MDA}\right.$ free $\left.{ }^{*} \mathrm{DPBM}\right)=\mathrm{c} /[(1-\mathrm{c})(2.5-\mathrm{c})]$ equ. 1
In the Arrhenius plot of MDA free or $\mathrm{Ke}$ in dependence of temperature activation energy $E A=18 \mathrm{~kJ} /$ mole was obtained.

When the equilibrium state was reached, the mixture was precipitated in maleic acidic water. After precipitation the equilibrium in solution was no longer valid, MDA free and maleic acid reacted to a soluble salt remaining in the filtrate.

The reaction between 2.5m DPBM and $1 \mathrm{~m}$ MDA was followed in solution by determining the free MDA content and the viscosity at $25^{\circ} \mathrm{C}$ as measure for the molecular weight. FTIR, DSC and $C^{13}$ NMR data in the literature [47-50] indicated that DPBM reacted with MDA to MDADPBM in a quick reaction. At temperatures higher than $150^{\circ} \mathrm{C}$ DPBM in excess reacted to the polymer. In IR a quick loss of $50 \%$ primary amine and maleimide were observed and instead of maleimide the succinic group occurred. From

Table 6: Conversion c to prepolymers in $40 \% / 55 \%$ solution at $120^{\circ} \mathrm{C}$, viscosity $v$ at $25^{\circ} \mathrm{C}$

\begin{tabular}{|c|c|c|c|}
\hline MDAfree & $\mathbf{c}^{*}$ & viscosity v (40/55\%) & MDA free *v (40/55\%) \\
\hline \hline$\%$ & mole & cSt & $\%^{*} \mathrm{cSt}$ \\
\hline 18 & 0 & $5 / 15$ & $90 / 270$ \\
\hline 9 & 0.5 & $7 / 21$ & $63 / 189$ \\
\hline 6 & 0.83 & $9.5 / 30$ & $57 / 180$ \\
\hline 1.8 & 0.9 & $20 / 70$ & $36 / 126$ \\
\hline 0 & (precipitate) & 1 & $20 / 40$ \\
\hline
\end{tabular}

${ }^{*} \mathrm{C}=(18-\mathrm{MDA}$ free $) / 18 ; 18$ was the initial concentration of MDA in the mixture 2.5DPBM/1MDA. 
Table 7: MDA Free and the Constant of Equilibrium Ke as a Function of Temperature. Data of Figure 3

\begin{tabular}{|c|c|c|c|c|c|}
\hline$T$ & $\mathbf{t}$ & $10^{3} / \mathrm{T}$ & MDA free & c & $\mathrm{Ke}$ \\
\hline${ }^{\circ} \mathrm{C}$ & $\mathrm{h}$ & $\mathrm{K}^{-1}$ & $\%$ & mole & $\mathrm{mole}^{-1}$ \\
\hline 120 & 4 & 2.545 & 4 & 0.78 & 2.06 \\
\hline 100 & 3.75 & 2.681 & 3 & 0.83 & 2.92 \\
\hline 80 & 3.5 & 2.833 & 2 & 0.89 & 5.03 \\
\hline 60 & 3.25 & 3.003 & 1 & 0.94 & 10.04 \\
\hline 40 & 3 & 3.195 & 0.7 & 0.96 & 15.58 \\
\hline 20 & 2.75 & 3.413 & 0.4 & 0.98 & 32.23 \\
\hline
\end{tabular}

these results it was concluded that one double bond of DPBM reacted with one MDA in a quick reaction.

In Figure 2 the Michael reaction was described as formula. The double bond content of $100 \%$ for DPBM was reduced to $82 \%$ in the mixture and reached $32 \%$ after reaction to the addition product DPBMMDA.

The balances of weight and heat were set up. The heats of formation were calculated from the heats of combustion according to van Krevelen [42,43]:

For the endothermic reaction a heat consumption of $18 \mathrm{~kJ} /$ mole was introduced, which had been derived from MDAfree or Ke in dependence of temperature.

Reaction to the addition product MDADPBM hreac ex/cal $=+16 /+16 \mathrm{~J} / \mathrm{g}$; Double bond $81.9=$ $(358 / 4)+(4 / 1093)=32 \%($ DPBM $100 \%$ double bond content)

F1: 2.5DPBM +1MDA = MDADPBM +1.5DPBM

IMW $895+198=556+537$

$H-1193.75+60+18=-399.5-716.25$

The reactions of MDADPBM and 1.5 DPBM to 2.5MDADPBpol were followed by DSC measurements in Figure 3.

In Figure 3 the heat flux was measured for DPBM and for the adduct comprising $2.5 \mathrm{~m}$ DPBM and $1 \mathrm{~m}$
MDA at constant heating rate. DPBM fused at $150^{\circ} \mathrm{C}$ under $90 \mathrm{~J} / \mathrm{g}$ heat uptake and polymerized at $250^{\circ} \mathrm{C}$ under heat evolution of-265J/g, which was higher than those of $-197 \mathrm{~J} / \mathrm{g}$ [3] and $-181 \mathrm{~J} / \mathrm{g}$ [44] given in the literature. For $\mathrm{BMI}$ a very small heat of fusion was detected at $80^{\circ} \mathrm{C}$ and at $230^{\circ} \mathrm{C}$ the heat of polymerization amounted $-190 \mathrm{~J} / \mathrm{g}$. The heat of polymerization of one double bond $85 \mathrm{~kJ} /$ mole [46] was introduced into the balance of weight and heat. Under the assumption that in a first step the molten adduct MDADPBM polymerizes and in a second step the molten DPBM polymerized with only one double bond, the following balances were set up:

hpol ex/cal $=1-0.12 \mathrm{~kJ} / \mathrm{g} ;$ Double bond $32=>$ $(358 / 4)^{*}(2.5 / 1093)=21 \%$

F2: $\quad$ MDADPBM $+1.5 \mathrm{DPBM}=$ MDADPBM + 1.5DPBMpol

MW $556+537=556+537=1093$

$\mathrm{H}-399.5-716.25+1.5^{\star} 85=-399.5-843.75$

hpol ex/cal $=1-0.08 \mathrm{~kJ} / \mathrm{g}$; Double bond $21 \% \Rightarrow$ $\left.(358 / 4)^{*} 1.5 / 1093\right)=12 \%$

F3; MDADPBM +1.5DPBMpol = MDA2.5DPBMpol

MW $556+537=1093$

$\mathrm{H}-399.5$ - 843.75- $85=-1328.25$

hpol ex/cal =-0.19/-0.19kJ/g; Double bond $81.9=>12 \%$ F2 +F3: MDA DPBM +1.5DPBM= MDA2.5DPBMpol

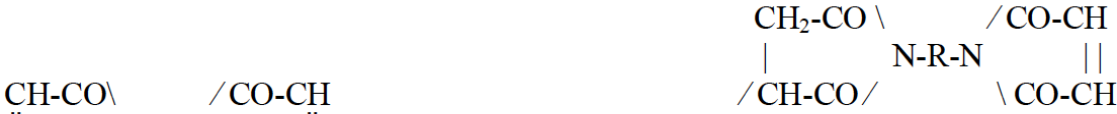

$$
\begin{aligned}
& \|_{\mathrm{CH}-\mathrm{CO} /}^{\mathrm{N}} / \stackrel{\mathrm{CO}-\mathrm{CH}}{\|}+\mathrm{NH}_{2}-\mathrm{R}-\mathrm{NH}_{2}=\mathrm{NH}_{2}-\mathrm{R}-\mathrm{NH} \\
& +1.5 \mathrm{DPBM} \\
& +1.5 \mathrm{DPBM} \\
& \mathrm{R}=-\mathrm{C}_{6} \mathrm{H}_{4}-\mathrm{CH}_{2}-\mathrm{C}_{6} \mathrm{H}_{4}-
\end{aligned}
$$

Figure 2: Michael reaction of 2.5m DPBM and 1m MDA to the adduct MDADPBM. 
DSC of DPBM and BMI

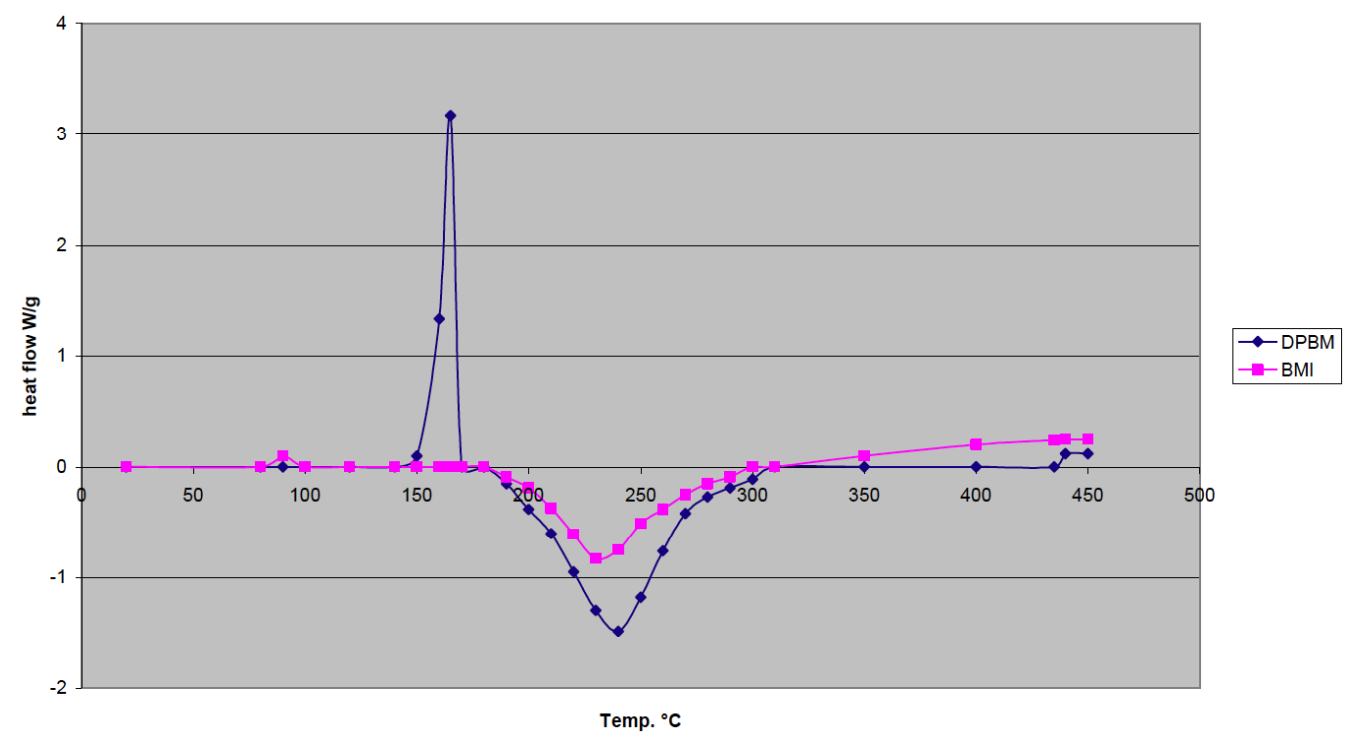

Figure 3: DSC $20 \mathrm{~K} / \mathrm{min}$ heating rate under $\mathrm{N}_{2}$ : DPBM heat of fusion $0.09 \mathrm{~kJ} / \mathrm{g}$ at $155^{\circ} \mathrm{C}$, heat of polymerization $-0.265 \mathrm{~kJ} / \mathrm{g}$ at $240^{\circ} \mathrm{C}$ and $\mathrm{Tg}$ at $435^{\circ} \mathrm{C}$. BMI heat of polymerization $-0.190 \mathrm{~kJ} / \mathrm{g}$ at $230^{\circ} \mathrm{C}$.

MW $556+537=1093$

$H-399.5-716.25-2.5^{\star} 85=-1328.25$

Giulio [47] investigated the same composition 2.5DPBM/1MDA and observed at $164^{\circ} \mathrm{C}$ after $5 \mathrm{~h}$ a double bond reduction from 70 to $40 \%$ comparable with F1: 82 to $32 \%$ and at $233^{\circ} \mathrm{C}$ after $5 \mathrm{~h}$ a residual double bond content of $30 \%$ comparable with F2: 32 to $21 \%$.

When $\mathrm{Hpol}=85 \mathrm{~kJ} / \mathrm{mole}$ was introduced into the balance, measured and calculated heats of polymerization were hpol ex/cal= $-0.19 /-0.19 \mathrm{~kJ} / \mathrm{g}$.

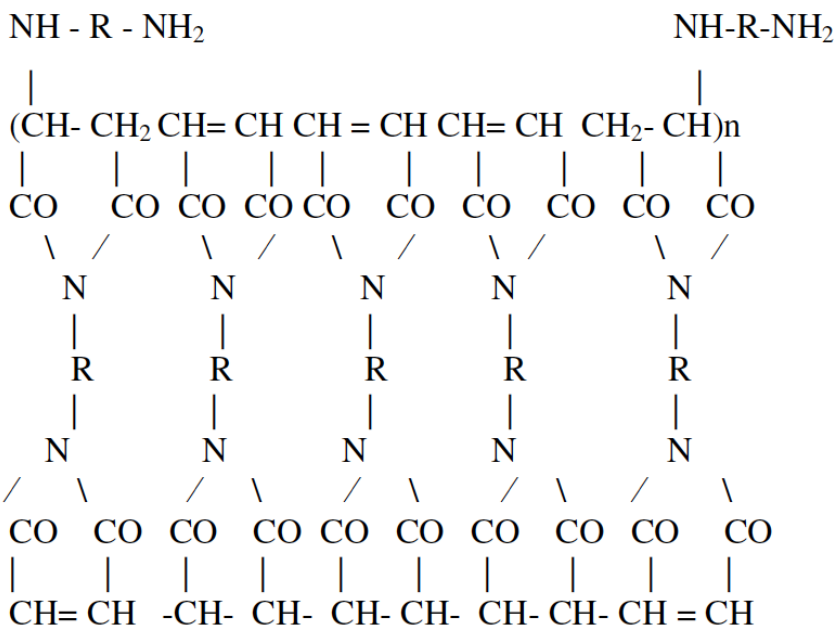

Figure 4: Polymerization of MDA and 2.5DPBM to MDA2.5DPBMpol with a double bond content of $12 \%$.

Under the assumption that DPBM polymerized with only one double bond to a linear chain with a double bond content of $50 \%$, the Succinimide to Maleimide ratio $1 / 1$ was expected

In Figure 5 Poly DPBM with the Succinimide/ Maleimide ratio $=1 / 1$ was depicted.

$$
\begin{aligned}
& n D P B M=(-\mathrm{CH}-\mathrm{CH}-\mathrm{CH}-\mathrm{CH}-\mathrm{CH}-\mathrm{CH}-) n
\end{aligned}
$$

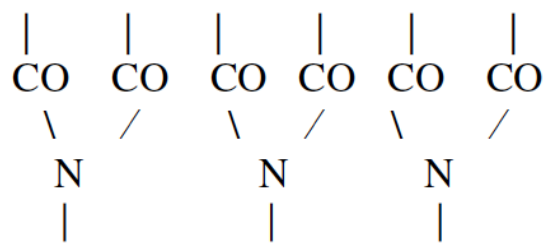

$$
\begin{aligned}
& \begin{array}{lll}
R & R & R \\
\text { I } & \text { I } & \text { I }
\end{array}
\end{aligned}
$$

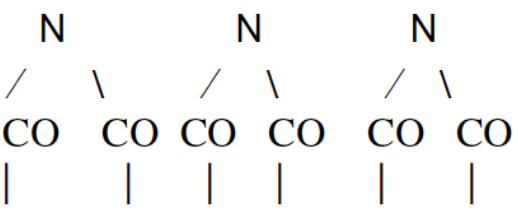

$$
\begin{aligned}
& \mathrm{CH}=\mathrm{CH} \quad \mathrm{CH}=\mathrm{CH} \quad \mathrm{CH}=\mathrm{CH}
\end{aligned}
$$

Figure 5: Reaction of DPBM to PolyDPBM with a double bond content of $50 \%$.

The balance of heat and mass was performed for Figure 5 in F5

hpol ex/cal $=-0.26 /-0.23 \mathrm{~kJ} / \mathrm{g} ;$ Succinimide/Maleimide $=1 / 1$; double bond content $50 \%$

F5: 3DPBM = 3DPBMpol 
TGA of DPBM and B21

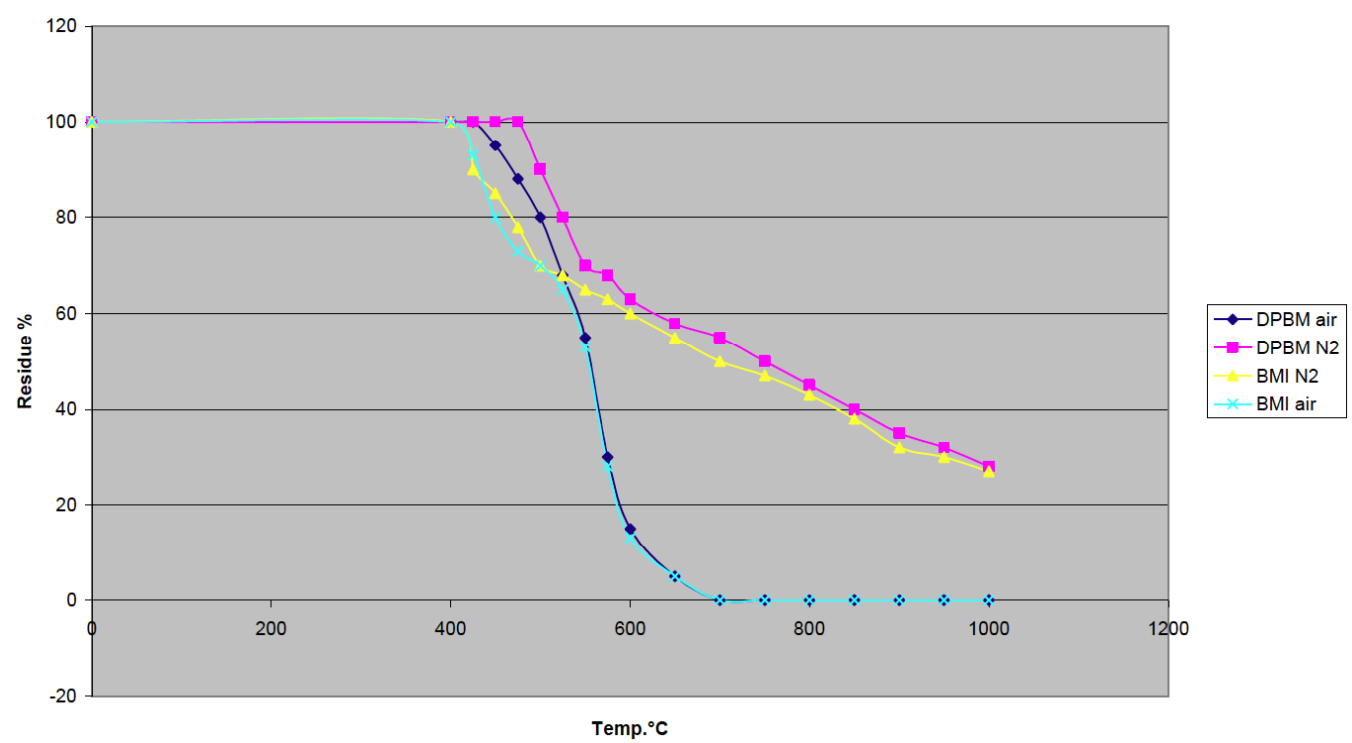

Figure 6: TGA 20K/min $\mathrm{N}_{2}$ and air of DPBM (DPBMpol) and BMI (MDA2.5.DPBMpol).

MW $3 * 358=3 * 358$

$H-3^{*} 477.5-3^{*} 85=-1687.5$

According to Loustalot [48] after $24 \mathrm{~h}$ at $200^{\circ} \mathrm{C}$ the ratio of Succinimide to Maleimide was $2 / 1$. In this case a much higher heat of polymerization was obtained by calculation according F5a.

hpol= ex/pol $-0,26 /-0.32 \mathrm{~kJ} / \mathrm{g} ;$ Succinimide/Maleimide $=2 / 1$; double bond content $33 \%$

F5a 3DPBM $=3$ DPBMpol

$\mathrm{H}-3^{*} 477.5-4 * 85=-1772.5$

DPBM and MDA2.5DPBM were cured to DPBMpol and MDA25DPBMpol during $24 \mathrm{~h}$ at $220^{\circ} \mathrm{C}$. TGA measurements were taken in air and nitrogen at $20 \mathrm{~K} / \mathrm{min}$ heating rate. In Figure 6 DPBM (DPBMpol) showed the highest heat resistance up to $550^{\circ} \mathrm{C}$ under nitrogen followed by that under air. BMI (MDA2.5DPBMpol) started to degrade at $450^{\circ} \mathrm{C}$ and showed two steps of decomposition one at 475 and another at $550^{\circ} \mathrm{C}$.

In nitrogen DPBM exerted the first degradation at $490^{\circ} \mathrm{C}$ and the second at $600^{\circ} \mathrm{C}$ and $70 \%$ residue, in air DPBM degraded at $450^{\circ} \mathrm{C}$. Under nitrogen BMI started to decompose at $400^{\circ} \mathrm{C}$ followed by a second step of degradation at $500^{\circ} \mathrm{C}$ and $75 \%$ residue, in air $\mathrm{BMI}$ initiated degradation at $400^{\circ} \mathrm{C}$ and $450^{\circ} \mathrm{C}$ at $70 \%$ residue.

The events under nitrogen could be expressed by balances of weight and mass.
Degradation of DPBMpol under $\mathrm{N}_{2}$

hdec ex $/ \mathrm{cal}=/-0.02 \mathrm{~kJ} / \mathrm{g} ; \mathrm{Rdec}$ ex $/ \mathrm{cal}=70 / 69 \%$ at $490^{\circ} \mathrm{C}$

F6: $\mathrm{C}_{21} \mathrm{H}_{14} \mathrm{~N}_{2} \mathrm{O} 4=4 \mathrm{CO}+\mathrm{C}_{17} \mathrm{H}_{14} \mathrm{~N}_{2}$

MW $358=112+246$

H- $562.5-7=-444-125.5$

hdec ex $/ \mathrm{cal}=/ 0.40 \mathrm{~kJ} / \mathrm{g} ; \mathrm{Rdec}$ ex $/ \mathrm{cal}=30 / 34 \%$ at $600^{\circ} \mathrm{C}$

F7: $\mathrm{C}_{17} \mathrm{H}_{14} \mathrm{~N}_{2}=2 \mathrm{NH}_{3}+\mathrm{C}_{6} \mathrm{H}_{6}+0.5 \mathrm{C}_{2} \mathrm{H}_{4}+10 \mathrm{C}$

MW $246=34+78+14+120$

$H-125.5+142.5=-92+83+26$

hdec ex $/$ cal $=0.40 / 0.38 \mathrm{~kJ} / \mathrm{g} ;$ Rdec ex $/$ cal $=30 / 34 \%$

$\mathrm{F} 8=\mathrm{F} 6+\mathrm{F} 7: \mathrm{C}_{21} \mathrm{H}_{14} \mathrm{~N}_{2} \mathrm{O} 4=4 \mathrm{CO}+2 \mathrm{NH}_{3}+\mathrm{C}_{6} \mathrm{H}_{6}+0.5 \mathrm{C}_{2} \mathrm{H}_{4}$ $+10 \mathrm{C}$

MW 359 $=112+34+78+14+120$

$H-591+164=-444-92+83+26$

Degradation of MDA2.5DPBMpol under $\mathrm{N}_{2}$ hdec ex $/$ cal $=/-0.03 \mathrm{~kJ} / \mathrm{g} ;$ Rdec ex $/ \mathrm{cal}=70 / 74$ at $400^{\circ} \mathrm{C}$ F9: $\mathrm{C}_{65.5} \mathrm{H}_{49} \mathrm{~N}_{7} \mathrm{O}_{10}=10 \mathrm{CO}+\mathrm{C}_{55.5} \mathrm{H}_{49} \mathrm{~N}_{7}$

MW $1093=280+813$

$H-1328.25-28=-1110-240.25$

hdec ex $/ \mathrm{cal}=/ 0.45 \mathrm{~kJ} / \mathrm{g} ; \mathrm{Rdec}$ ex $/ \mathrm{cal}=40 / 37.9 \%$ at $450^{\circ} \mathrm{C}$

F10: $\mathrm{C}_{55.5} \mathrm{H}_{49} \mathrm{~N}_{7}=2 \mathrm{C}_{6} \mathrm{H}_{6}+7 \mathrm{NH}_{3}+\mathrm{C}_{2} \mathrm{H}_{2}+3.5 \mathrm{C}_{2} \mathrm{H}_{4}+$ $34.5 \mathrm{C}$

MW $813=156+119+26+98+414$

$H-240.25+493.25=166-322+227+182$ 
hdec ex $/$ cal $=0.42 / 0.43 \mathrm{~kJ} / \mathrm{g} ;$ Rde ex $/$ cal $=40 / 37.9 \%$

$\mathrm{F} 11=\mathrm{F} 9+\mathrm{F} 10: \mathrm{C}_{65.5} \mathrm{H}_{49} \mathrm{~N}_{7} \mathrm{O}_{10}=10 \mathrm{CO}+2 \mathrm{C}_{6} \mathrm{H}_{6}+7 \mathrm{NH}_{3}+$ $\mathrm{C}_{2} \mathrm{H}_{2}+3.5 \mathrm{C}_{2} \mathrm{H}_{4}+34.5 \mathrm{C}$

MW $1093=280+156+119+26+98+414$

$\mathrm{H}-1328.25+471.25=-1110+166-322+227+182$

The experimental hdec ex were obtained from TGA measurement, which were run with different heating rates. The experimental DSC data of Figure 6 were compared with those calculated: DPBM decomposed in $\mathrm{N}_{2}$ under heat uptake $0.40 / 0.38 \mathrm{~kJ} / \mathrm{g}$ and $\mathrm{BMI}$ degraded in $\mathrm{N}_{2}$ under heat uptake $0.42 / 0.43 \mathrm{~kJ} / \mathrm{g}$.

In Table 8 commercial and experimental products with various ratios MDA/DPBM were collected and compared in respect to their energies of fracture GIC and their heat stabilities quantified in $\mathrm{Tg}$ and $\mathrm{Tdec}$.

In Figure 7 the temperature of degradation Tdec, the glass transition $\mathrm{Tg}$, the heat of polymerization hpol and the energy of fracture $G_{I C}$ were correlated with the amount of MDA.

According to Figure $7 \mathrm{BMI}$ comprising 2.5m DPBM and $1 \mathrm{~m}$ MDA with $18 \%$ MDA was a fair compromise between $90 \mathrm{~J} / \mathrm{m}^{2}$ energy of fracture and $340^{\circ} \mathrm{C}$ glass transition temperature. The critical energy of fracture GIC in dependence of the MDA content showed sigmoide shape. At low MDA concentration the relation between $G_{I C}$ and the weight fraction of MDA followed the parabolic equation 2

Table 8: The Influence of the Molar Ratio X/DPBM on the Heat of Polymerization hpol, the Glass Transition Temperature $\mathrm{Tg}$ and the Temperature of Degradation Tdec as well as on the Content of MDA Free and the Energy of Fracture $\mathrm{G}_{\mathrm{IC}}$

\begin{tabular}{|c|c|c|c|c|c|c|c|}
\hline BMI & $\begin{array}{l}\text { X/DPBM } \\
X=\text { MDA }\end{array}$ & $\begin{array}{c}\text { DPBM - } \\
\text { w\% }\end{array}$ & $\begin{array}{c}\text { hpol kJ/g } \\
\text { kJ/g }\end{array}$ & $\begin{array}{c}\mathrm{Tg} / \mathrm{Tdec} \\
{ }^{\circ} \mathrm{C}\end{array}$ & $\begin{array}{c}\text { MDA free } \\
\text { w\% }\end{array}$ & $\begin{array}{l}\mathbf{G}_{\mathrm{IC}} \\
\mathrm{J} / \mathrm{m}^{2}\end{array}$ & CAS \\
\hline & $0 / 1$ & 100 & 0.27 & $435 / 490$ & 0 & 0 & $13676-54-5$ \\
\hline & $1 / 3$ & 91 & 0.25 & $370 / 480$ & 1,5 & 50 & \\
\hline & $1 / 2.5$ & 82 & 0.23 & $330 / 475$ & 3 & $100^{*}$ & \\
\hline & $1 / 2$ & 78 & 0.21 & $320 / 470$ & 6 & $130^{*}$ & \\
\hline & $1 / 1$ & 64 & 0.16 & $290 / 450$ & 8 & $180^{*}$ & \\
\hline Kerimid 601 & $1 / 2.5$ & & & & 8 & 34 & 89963-68-8 \\
\hline Kerimid 601 & $1 / 1$ & & 0.14 & & 8 & & $130777-92-3$ \\
\hline Kerimid 601 & $1 / 2$ & & & & 6 & & $9063-71-2$ \\
\hline \multirow[t]{2}{*}{ Kerimid 607} & $1 / 1$ & & & & & & $35064-37-0$ \\
\hline & $X=$ DABPA & & & & & & $1745-89-7$ \\
\hline \multirow[t]{6}{*}{ Matrimid 5292} & $1 / 3.4$ & 80 & & & & 30 ** & \\
\hline & $1 / 2$ & 70 & & & & $60^{\star *}$ & \\
\hline & $1 / 1.6$ & 65 & & & & $98^{* *}$ & \\
\hline & $1 / 1.3$ & 60 & & & & $123^{\star *}$ & \\
\hline & $1 / 0.9$ & 50 & & $273 / 430$ & & 217 & \\
\hline & X= Dipropen & oxybenzoph & & & & & \\
\hline \multirow[t]{2}{*}{ Compimide TM123 } & $1 / 2$ & & & $261 / 459$ & & 439 & $109423-33-8$ \\
\hline & $\mathrm{X}=\mathrm{m}-\mathrm{Aminol}$ & hydrazide & & & & & $5351-17-76$ \\
\hline \multirow[t]{2}{*}{ Compimide 796} & $1 / 2$ & & & & & 63 & 106856-59-1 \\
\hline & $X=$ Aminmop & & & & & & $591-27-5$ \\
\hline \multicolumn{2}{|c|}{ Compimide 353} & & 0.22 & & & & $51569-11-0$ \\
\hline \multicolumn{3}{|c|}{ Compimide 183} & & & & & $98725-11-2$ \\
\hline
\end{tabular}

${ }^{*}$ curing $72 \mathrm{~h} 130^{\circ} \mathrm{C}, 6 \mathrm{~h} 220^{\circ} \mathrm{C}$ Mittal [8], ** $3 \mathrm{~h} 160^{\circ} \mathrm{C}, 4 \mathrm{~h} 210^{\circ} \mathrm{C}, 5 \mathrm{~h} 240^{\circ} \mathrm{C}[3]$.

Matrimid 5292 (Ciba Geigy BASF). Kerimid (Rhone Poulenc), Compimide (Evonic Industries). 
Influence of MDA

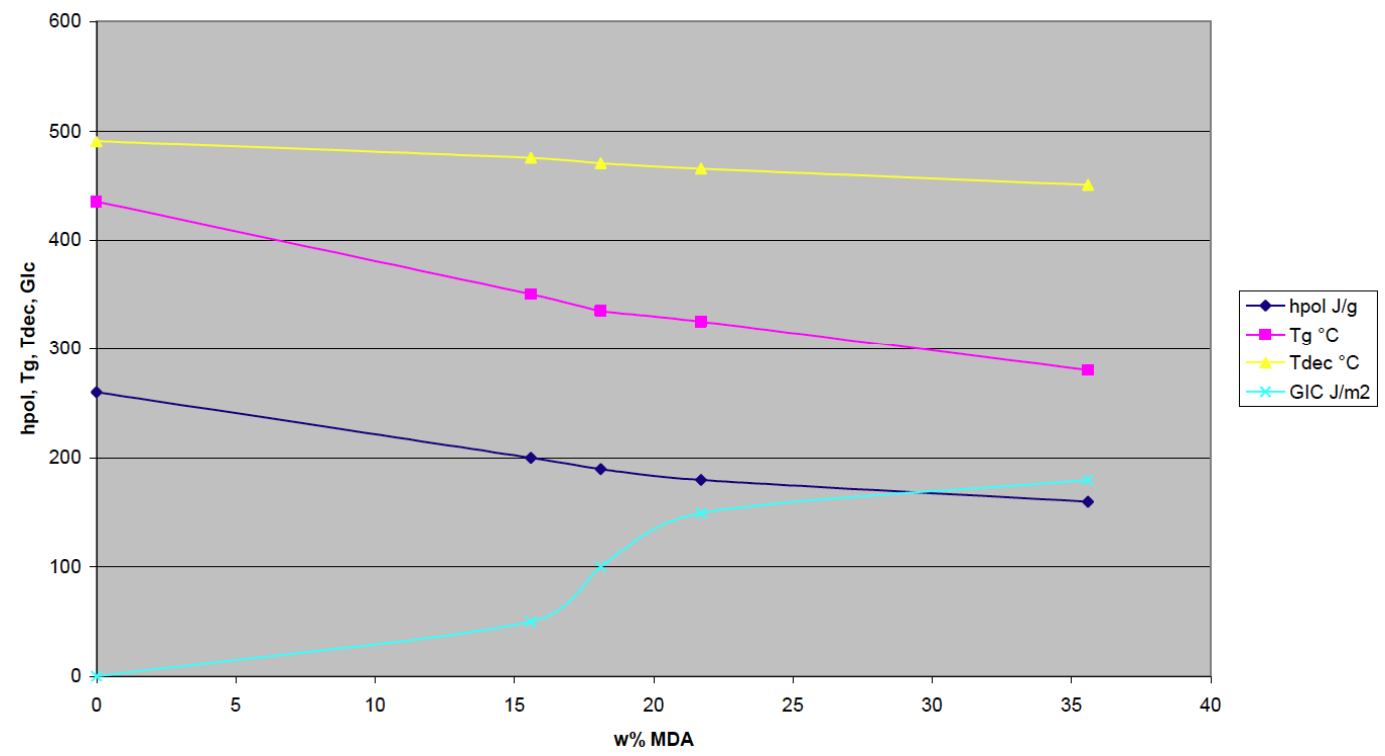

Figure 7: For BMI the energy of fracture $\mathrm{G}_{\mathrm{IC}}$, increased with increasing amount of MDA, the temperatures of degradation Tdec, the glass temperatures $\mathrm{Tg}$ and the heats of polymerization hpol decreased with increasing amount of MDA.

\section{$\mathrm{G}_{I C}=3600 *(w \% M D A / 100)^{3} \quad$ equ.2}

The Reaction Product of 2.5moles DPBM and 1 mole A

The Michael reaction was also performed with the less expensive aniline $A$ in order to obtain a 2.5DPBM/1A adduct, which was further polymerized to the resin A2.5DPBMpol.

The reaction was transformed in balances of heat and weight using the same heats of reaction for addition and polymerization already used with MDA.

$\mathrm{h}$ reac ex $/$ cal $=10.018 \mathrm{~kJ} / \mathrm{g}$

$\mathrm{F} 12$ 2.5DPBM + A = ADPBM +1.5DPBM

MW $895+93=451+537$

H $2.5 * 477.5+9+18=-450.5-716.25$

$\mathrm{hpol}$ ex $/ \mathrm{cal}=/ 0.24 \mathrm{~kJ} / \mathrm{g}$

F13: $A D P B M+1.5 D P B M=A 2.5 D P B M p o l$

MW $451+537=988$

H- $450.5-716.25-2.5^{\star} 85=-1379.25$

In the past Technochemie offered BMI resins based on $\mathrm{m}$ Aminobenzoic hydrazide $\mathrm{ABH}$ and $\mathrm{m}$ Aminophenol AP.

In Table 9 the properties of BMI based on MDA, A (Aniline), $\mathrm{ABH}$ ( $\mathrm{m}$-Aminobenzoic hydrazide) and $\mathrm{AP}$ ( $\mathrm{m}$ - Aminophenol) were compared.
According to Table 9 the highest glass temperature Tg was achieved by BMI based on $A$.

\section{Reaction of DPBM with Diallybisphenol A via Diels Alders Reaction}

DPBM reacted with the aromatic allyl compounds [44,45,51] like diallylbisphenol A DABPA, dipropargylether of bisphenol A DPBPA and Bis (propenyl phenoxybenzophenon) BPPB via Diels Alder reaction. A recent publication [15] described the reactions of DPBM with dipropargylether of bisphenol $A$ ether DPBPA and hexafluorpropyl bisaniline. The commercial resins such as Matrimide 5292 based on Diallylbisphenol A exerted a fraction energy $G_{I C}$ $=210 \mathrm{~J} / \mathrm{m}^{2}$ and Compimide TM123 based on Dipropenylphenoxybenzophenone $\mathrm{G}_{\mathrm{IC}}=439 \mathrm{~J} / \mathrm{m}^{2}$. For Diallylbisphenol $A$ and DPBM the fracture energy $G_{I C}$ showed no linear but parabolic relation between $G_{1 C}$ and the amount of DABPA gibven as weight fraction.

$\mathrm{G}_{\mathrm{IC}}=2500 *(\mathrm{w} \% \mathrm{DABPA} / 100)^{3}$

equ.3

The reaction between DPBM and Diallylbisphenol A DABPA was described in balances of weight and heat using $85 \mathrm{~kJ} / \mathrm{mole}$ as heat of polymerization:

$\mathrm{hpol}$ ex $/ \mathrm{cal}=/-0.13 \mathrm{~kJ} / \mathrm{g}$

F14: $\mathrm{DPBM}+\mathrm{DABPA}=\mathrm{DABPADPBM}$

MW $358+308=666$

$\mathrm{H}-477.5-385.5-85=-946$ 
Table 9: $\quad$ BMI resin of 1m DPBM with X Moles Amine via Michael Addition

\begin{tabular}{|c|c|c|c|c|c|}
\hline Product & Kerimide 601 & Homide 259 & & Evonik & Evonik \\
\hline Formula & $\mathrm{C}_{34} \mathrm{H}_{28} \mathrm{~N}_{4} \mathrm{O}_{4}$ & $\mathrm{C}_{65,5} \mathrm{H}_{49} \mathrm{~N}_{7} \mathrm{O}_{10}$ & $\mathrm{C}_{58.5} \mathrm{H}_{42} \mathrm{~N}_{6} \mathrm{O}_{10}$ & $\mathrm{C}_{27} \mathrm{H}_{21} \mathrm{~N}_{3} \mathrm{O}_{5}$ & $\mathrm{C}_{49} \mathrm{H}_{37} \mathrm{~N}_{7} \mathrm{O}_{9}$ \\
\hline MW g/Mole & 556 & 1093 & 988 & 467 & 867 \\
\hline $\mathrm{hpol} \mathrm{kJ/g}$ & -0.18 & -0.19 & -0.24 & -0.20 & -0.11 \\
\hline $\mathrm{Tg}^{\circ} \mathrm{C}$ & 280 & 350 & 380 & 300 & 287 \\
\hline hcomb kJ/g & $-30,5$ & -29.0 & -28.1 & -27.7 & -27.0 \\
\hline $\operatorname{Tdec}{ }^{\circ} \mathrm{C}$ & 450 & 470 & 430 & 450 & 450 \\
\hline$x$ & 1 & 0.4 & 0.4 & 1 & 0.5 \\
\hline Reaction & Michael & Michael & Michael & Michael & Michael \\
\hline $\mathrm{GIC} \mathrm{J/ \textrm {m } ^ { 2 }}$ & 34 & 100 & 75 & & 65 \\
\hline
\end{tabular}

Table 10: BMI Resin of 1m DPBM and x Moles of DABPA (Diallylbisphenol A), DPBPA Dipropargylether of Bis Phenol A and BPPB Bispropenylphenoxybenzophenone) via Diels Alder Reaction

\begin{tabular}{|c|c|c|c|}
\hline Comonomer & DABPA & DPBPA & BPPB \\
\hline \hline Product & Matrimid 5292 & & Evonik \\
\hline Company & Ciba Geigy & $\mathrm{C}_{67} \mathrm{H}_{51} \mathrm{~N}_{4.5} \mathrm{O}_{11}$ & $\mathrm{C}_{52} \mathrm{H}_{40} \mathrm{~N}_{2} \mathrm{O}_{7}$ \\
\hline Formula & $\mathrm{C}_{42} \mathrm{H}_{38} \mathrm{~N}_{2} \mathrm{O}_{6}$ & 1094 & 804 \\
\hline $\mathrm{MW} \mathrm{g/Mole}$ & 666 & -945 & ${ }^{*}-2702$ \\
\hline $\mathrm{Hf}(\mathrm{kJ} / \mathrm{mole}$ & -940 & 330 & 261 \\
\hline $\mathrm{Tg}{ }^{\circ} \mathrm{C}$ & 280 & -29.5 & -31.7 \\
\hline $\mathrm{hcomb} \mathrm{kJ/g}$ & -31.6 & 450 & 450 \\
\hline $\mathrm{Tdec}{ }^{\circ} \mathrm{C}$ & 450 & 1.13 & 2.5 \\
\hline $\mathrm{hdec} \mathrm{kJ} / \mathrm{g}$ & 1.19 & 32 & 25 \\
\hline $\mathrm{Rdec} \%$ & 18 & $15)$ & $109423-33-8$ \\
\hline $\mathrm{CAS} / \mathrm{Lit}$ & $1745-89-7$ & 0.4 & 1 \\
\hline $\mathrm{X}$ & 1 & Diels Alder & Diels Alder \\
\hline Reaction & Diels Alder & & 440 \\
\hline $\mathrm{GIC} \mathrm{J/m2}$ & 210 & & \\
\hline
\end{tabular}

\section{Styrene- Maleimide Copolymers MMI}

BMI resins were more related with styrene monomaleimide copolymers than with polyimides, because both carry their imide bond in the side chain. From Phenylmaleimide, Xylylmaleimide and 2Bromophenyl maleimide styrene copolymers were synthesized with the aim of later prepreg production.
Equimolar mixtures of styrene and monomaleimides reacted to linear polymers with alternating styrene and maleimide molecules in the chain, as described in Figure 8.

Also $1 \mathrm{~m}$ DPBM was reacted with $1 \mathrm{~m}$ styrene and a cross linked, insoluble product was obtained. The polymers with monomaleimides were soluble and 


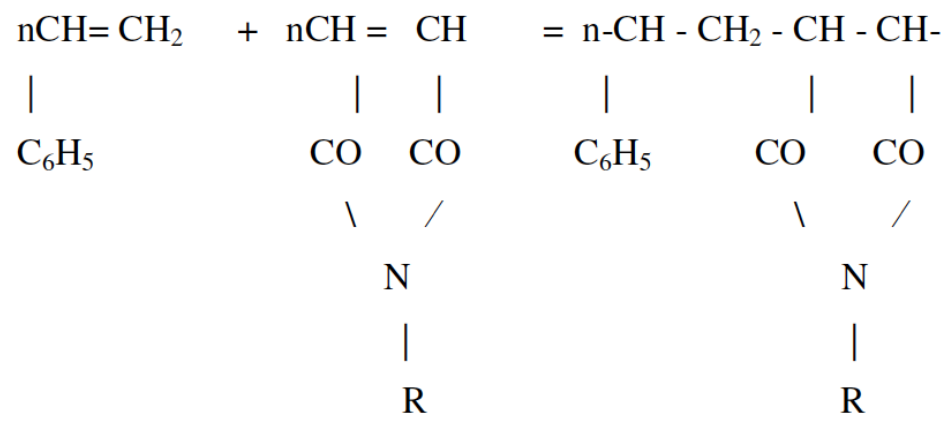

$\mathrm{R}=$ Phenylmaleimide, Xylylmaleimide, 2-Bromophenylmaleimide

Figure 8: Reaction of styrene and maleimide.

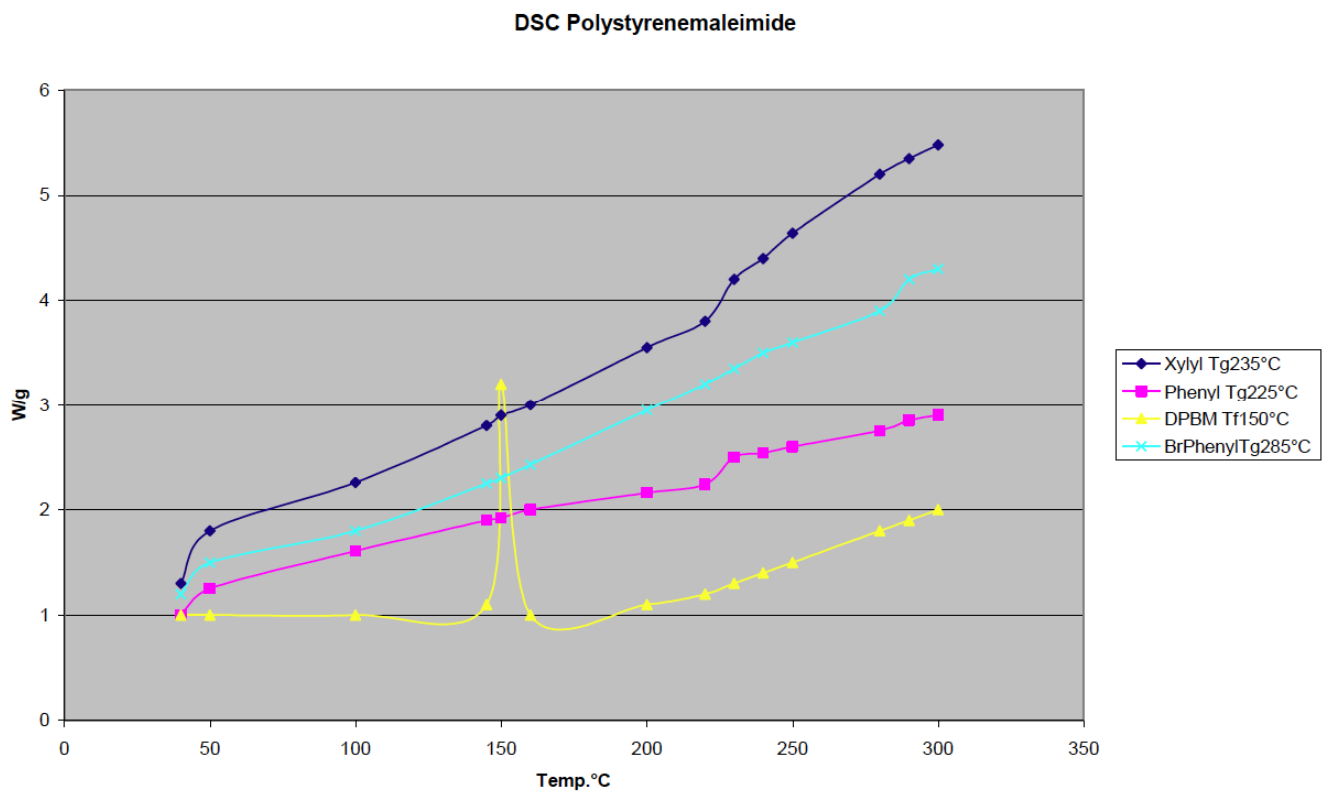

Figure 9: DSC 20K/min $\mathrm{N}_{2}$ of equimolar styrene Phenyl-, Xylyl- , 2- BrPhenyl- and DPBM- maleimide.

showed all well defined glass transition temperatures. The insoluble polymer with DPBM exerted a melting point at the melting point of DPBM, but evolved only half of the heat of melting. Therefore with high probability one could assume that one half of DPBM had reacted with both double bonds under cross linking and the other half remained not dissolved and melted as DPBM. All products were characterized by DSC measurements in Figure 9.

The literature postulated for the addition product of styrene or alpha methyl styrene with DPBM a cyclic structure [3]. In Figure 10 this structure was depicted.

A second DPBM should be attached in position $C_{1}$ under proliferation of the chain.

The obtained thermoplastic polymers MMI were characterized with their properties, which were given in Table 11.
BrPhenyl the 2-Bromophenylmaleimide Styrene copolymer showed the highest $\mathrm{Tg}$ and was chosen for

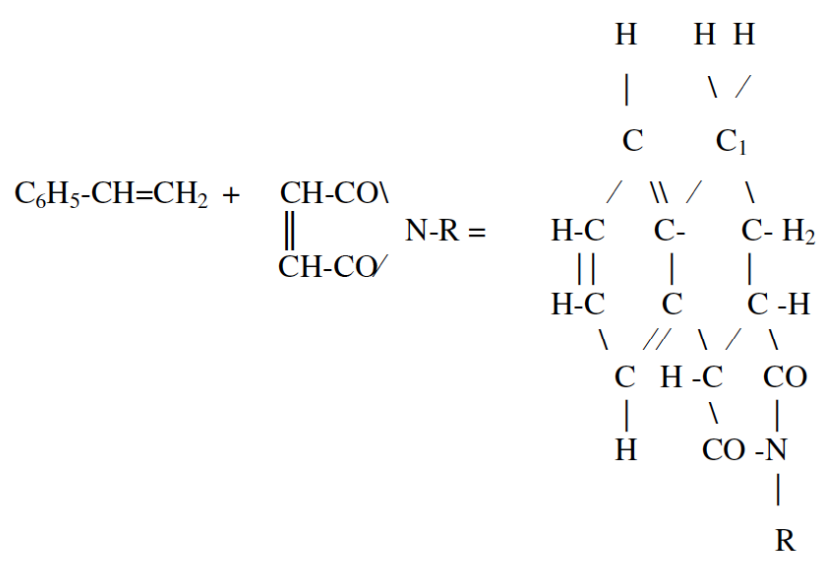

$\mathrm{R}=-\mathrm{CH}_{2}-\mathrm{C}_{6} \mathrm{H}_{4}-\mathrm{N}-(\mathrm{COCH})_{2}$

Figure 10: Reaction of Styrene DPBM according to literature. 
Table 11: Data of Styrene N-maleimide Copolymers MMI

\begin{tabular}{|c|c|c|c|}
\hline MMI & Xylyl & BrPhenyl & Phenyl \\
\hline \hline Formula & $\mathrm{C}_{20} \mathrm{H}_{19} \mathrm{NO}_{2}$ & $\mathrm{C}_{18} \mathrm{H}_{14} \mathrm{NO}_{2} \mathrm{Br}$ & $\mathrm{C}_{18} \mathrm{H}_{15} \mathrm{NO}_{2}$ \\
\hline $\mathrm{MW} \mathrm{g} / \mathrm{mole}$ & 305 & 356 & 227 \\
\hline $\mathrm{Hf} \mathrm{kJ} / \mathrm{mole}$ & -256 & -167 & -201 \\
\hline $\mathrm{hg} \mathrm{J} / \mathrm{g}$ & 1,8 & 0.20 & 0.8 \\
\hline $\mathrm{Tg}{ }^{\circ} \mathrm{C}$ & $/ 230$ & $/ 285$ & -32.6 \\
\hline $\mathrm{hcomb} \mathrm{kJ/g}$ & -33.9 & -25.1 & 460 \\
\hline $\mathrm{Tdec}{ }^{\circ} \mathrm{C}$ & 440 & 450 & 1.43 \\
\hline $\mathrm{hdec} \mathrm{kJ} / \mathrm{g}$ & 0.54 & 7 & 0.70 \\
\hline $\mathrm{Rdec} \%$ & 20 & 17 & \\
\hline
\end{tabular}

the manufacture of prepregs. In the case of BMI the Bprepreg consisted of $50 \%$ tissue and $50 \%$ (51\%MDADPBM +49\%DPBM). In the case of MMI the B-prepreg comprised $50 \%$ tissue and $50 \%$ (29\%Styrene $71 \%$ Bromophenylmaleimide). After curing the B-pregregs to laminates the resins had to be completely polymerized, in order to obtain optimized properties.

As in all balances of weight and heat $85 \mathrm{~kJ} / \mathrm{mole}$ was introduced as heat of polymerization:

Polymerization hpol ex $/$ cal $=1-0.48 \mathrm{~kJ} / \mathrm{g}$

F15: $\mathrm{C}_{8} \mathrm{H}_{8}+\mathrm{C}_{10} \mathrm{H}_{6} \mathrm{BrNO}_{2}=\mathrm{C}_{18} \mathrm{H}_{14} \mathrm{BrNO}_{2}$ pol

MW $104+252=356$

H $58-225.5-2 * 85=-337.5$

Decomposition hdec ex $/ \mathrm{cal}=/ 1.43 \mathrm{~kJ} / \mathrm{g} ;$ Rex $/ \mathrm{cal}=10 / 7 \%$

F16: $\mathrm{C}_{18} \mathrm{H}_{14} \mathrm{BrNO}_{2}=2 \mathrm{CO}+2 \mathrm{C}_{6} \mathrm{H}_{6}+\mathrm{Br}+0.5 \mathrm{~N}_{2}$ $+\mathrm{C}_{2} \mathrm{H}_{4}+2 \mathrm{C}$

MW $356=56+156+80+14+26+24$

$\mathrm{H}-337.5+508.5=-222+166+227$

In Figure 9 the glass temperatures were observed as steps in the heat flow curves. The sigma shaped steps with turning points were characterized by their height $W / g$ and width $T=20^{*} t$ at heating rate of $20 \mathrm{~K} / \mathrm{min}$. The width did not differ very much and was about $10^{\circ} \mathrm{C}$ in any case or $t=60 / 20=30 \mathrm{sec}$.

By differentiation a maximum was obtained with the coordinates height $/ 2=(\mathrm{W} / \mathrm{g}) / 2$ and width $=30 \mathrm{sec}$.

The area under the maximum was the heat flow integral and could be determined by integration $\int$ $\mathrm{d}(\mathrm{W} / \mathrm{g})^{*} 30$ or approximately by the area of the triangle with the height $(\mathrm{W} / \mathrm{g}) / 2$ and the width $30 \mathrm{sec}$.
$1 / 2 \mathrm{~W} / \mathrm{g}$

Heat flow integral $h g(J / g)=\int d(W / g)^{*} 60 * T / 20 \sim$ area of triangle $=0.5\left[1 / 2(\mathrm{~W} / \mathrm{g})^{*} 30 \mathrm{sec}\right]=7.5^{*} \mathrm{~W}^{*} \mathrm{sec} / \mathrm{g}$ equ. 4

$\mathrm{OW} / \mathrm{g}$

In Table 12 the so determined heats of glass transition $\mathrm{Hg}$, the glass temperatures $\mathrm{Tg}$ and the calculated entropies $\mathrm{Sg}$ were collected. As dT did not differ very much the value $10^{\circ} \mathrm{C}$ was taken in every case,

Stoliarov $[49,50]$ investigated charring polymers by DSC measurements and found for PEI a "melting heat or glass transition heat" of $1.0 \mathrm{~J} / \mathrm{g}$, which fits to the obtained value of $1.7 \mathrm{~J} / \mathrm{g}$. The observed heats and entropies of glass transition were much smaller than those for melting points. The sterically hindered Xylyl and BrPhenyl copolymers exerted higher $\mathrm{Sg}$ values than the non hindered Phenyl. The styrene- Phenyl polymer showed a yellow colour, whereas the styrene Xylyl and BrPhenyl polymers were of white colour. The lack of colour was caused by a breakdown of the conjugated system. For polymers, which change from liquid to solid state without heat development, the glass temperature was equal to the Kauzmann temperature $[51,52]$. In this case the enthalpy $\mathrm{Hg}$ as well as the entropy of glass transition $\mathrm{Sg}$ were zero. For polystyrene, PEI, PAI and for equimolar styrene maleimide the glass temperature was not equal to the Kauzmann temperature.

The mentioned PEI and PAl are well known under the brand names Ultem 1000 and Torlon $42030 \mathrm{~L}$ and styrene maleimide polymers are sold under the brand names Malecca by Denka Chemicals and styrene maleic acid anhydride copolymers under the brand 
Table 12: Non Crystalline Polymers their Glass Transition Temperature Tg, their Heat Flux W/g at Tg and Width of Temperature dT, Heat of Glass Transition Hg and Entropy of Glass Transition Sg

\begin{tabular}{|c|c|c|c|c|c|c|}
\hline Material & MW g/mole & $\mathrm{Tg}^{\circ} \mathrm{C} / \mathrm{K}$ & $\begin{array}{c}\mathrm{Hg} / \mathrm{hg} \\
\mathrm{J} / \mathrm{mole} / \mathrm{J} / \mathrm{g}\end{array}$ & $\begin{array}{c}\mathrm{Sg}=\mathrm{Hg} / \mathrm{Tg} \\
\mathrm{J} /\left(\mathrm{mole}^{\star} \mathrm{K}\right)\end{array}$ & heat flux W/g & $\mathrm{dT}^{\circ} \mathrm{C}$ \\
\hline PS & 104 & $100 / 373$ & $200 / 2.0$ & 0.5 & 0.27 & 10 \\
\hline PEI & 592 & $272 / 545$ & $592 / 1.7$ & 1.8 & 0.23 & 10 \\
\hline PAl & 354 & $217 / 490$ & $531 / 1.5$ & 1.1 & 0.20 & 10 \\
\hline DPBM & 358 & $435 / 708$ & $358 / 1.0$ & 0.5 & 0.13 & 10 \\
\hline BMI & 1093 & $320 / 593$ & $\begin{array}{l}\text { (TMA, no signal } \\
\text { in DSC) }\end{array}$ & & & \\
\hline \multicolumn{7}{|c|}{ Equimolar Styrene maleimide copolymers } \\
\hline Phenyl & $173+104$ & $225 / 498$ & $305 / 1.1$ & 1.1 & 0.15 & 10 \\
\hline Xylyl & $201+104$ & $230 / 503$ & $458 / 1.5$ & 0.92 & 0.2 & 10 \\
\hline BrPhenyl & $252+104$ & $285 / 558$ & $534 / 1.5$ & 0.96 & 0.2 & 10 \\
\hline DPBM & $358+104$ & $\begin{array}{r}\text { no } \mathrm{Tg} \text { but Tf } \\
\text { signal in DSC }\end{array}$ & & & & \\
\hline \multicolumn{7}{|c|}{ Equimolar Styrene maleic acid anhydride copolymer } \\
\hline & MW g/mole & $\operatorname{Tg}^{\circ} \mathrm{C} / \mathrm{K}$ & hcomb kJ/g & hdec kJ/g & Rdec \% & \\
\hline MSA & $116+104$ & $130 / 403$ & -25.7 & 2,6 & 0 & \\
\hline
\end{tabular}

name Dylarc by Nova Chemicals and Xirane by Polyscope Polymers. The styrene DPBM styrene polymer was cross linked and non soluble. No step for the glass temperature could be detected in the DSC. The observed melting point at $150^{\circ} \mathrm{C}$ and $0.035 \mathrm{~kJ} / \mathrm{g}$ heat of melting could be explained under the assumption that both double bonds of DPBM reacted with styrene $S$ and half of DPBM remained non reacted and non dissolved so that the expected heat of melting was $0.090 \mathrm{~kJ} / \mathrm{g}^{*}(358 / 462) / 2=0.035 \mathrm{~kJ} / \mathrm{g}$.

Heat resistant polymers compete with engineering plastics like polyamides as well as with metals like iron and aluminium. In Table 16 enthalpies and entropies were listed for iron, aluminium and crystalline polymers in comparison.
The thermoplastic polyamides achieved their high melting temperature by their high enthalpies caused by hydrogen bonds.

\section{FR- BMI Laminates and their Burning Behaviour}

Halogen free and bromine FR from Table 17 were applied by dry powder mixing to the $2.5 \mathrm{~m}$ DPBM $/ 1 \mathrm{~m}$ MDA BMI adduct, which thereafter was dissolved in DMF to obtain a $55 \%$ solution, which was used in the tube reactor combined with an impregnation device. The solution passed the tube in $4.4 \mathrm{~h}$. The temperature of reaction was $60^{\circ} \mathrm{C}$ and the output into a bath was $1.4 \mathrm{I} / \mathrm{h}$. The reacted solution filled a bath, in which the glass fabric US 2116 was led with a speed of $7.5 \mathrm{~m} / \mathrm{h}$. After twice dipping and drying a B-prepreg with about $50 \%$ resin content was obtained. The brominated flame

Table 13: Metals and Crystalline Polymers their Temperature of Melting Tm, their Heats and Entropies of Melting Hm and Sm

\begin{tabular}{|c|c|c|c|c|c|}
\hline Material & MW $\mathbf{g} / \mathbf{m o l e}$ & $\mathbf{T m}{ }^{\circ} \mathbf{C} / \mathbf{K}$ & Hm kJ/mole & hm $\mathbf{~ J / g}$ & Sm =Hm/Tm J/(mole $\left.\mathbf{~}^{*}\right)$ \\
\hline \hline Fe & 56 & $1528 / 1801$ & 15.0 & 0.268 & 8.3 \\
\hline Al & 27 & $660 / 938$ & 10.7 & 0.396 & 11.5 \\
\hline PE & 26 & $132 / 408$ & 7.5 & 0.288 & 18.8 \\
\hline PS cryst & 104 & $240 / 513$ & 9.2 & 0.089 & 17.0 \\
\hline PA6 & 113 & $220 / 493$ & 11.1 & 0.070 & 23.5 \\
\hline PA66 & 226 & $260 / 533$ & 20.1 & 0.075 & 37.7 \\
\hline
\end{tabular}


Table 14: Flame Retardants with their Formula, their Molecular Weight MW, their Temperature of Fusion Tf, Heat of Fusion hf, Temperature of Decomposition Tdec, Heat of Decomposition hdec, Residue R and their Char

\begin{tabular}{|c|c|c|c|c|c|c|c|c|c|}
\hline FR & formula & MW g/mole & Brom \% & Tf ${ }^{\circ} \mathbf{C}$ & Hf J/g & Tdec ${ }^{\circ} \mathbf{C}$ & hdec kJ/g & $\mathbf{R} \%$ & Char \\
\hline \hline TBrP & $\mathrm{C}_{10} \mathrm{H}_{4} \mathrm{NO}_{2} \mathrm{Br}_{3}$ & 410 & 58,5 & 149 & 50 & $300 / 310$ & $-0.006 / 0.006$ & 20 & $\mathrm{C}$ \\
\hline $\mathrm{ETBr}$ & $\mathrm{C}_{28} \mathrm{H}_{4} \mathrm{~N}_{2} \mathrm{O}_{4} \mathrm{Br}_{8}$ & 952 & 67,2 & 445 & 90 & $460 / 480$ & $-0.06 /-0.06$ & 12 & $\mathrm{C}$ \\
\hline $\mathrm{BCPP}$ & $\mathrm{C}_{5} \mathrm{H}_{9} \mathrm{O}_{5} \mathrm{P}$ & 180 & 0 & 215 & 120 & $310 / 350$ & $-0.1 /-0.1$ & 66 & $\mathrm{C}_{8}{ }^{*} \mathrm{P}_{2} \mathrm{O}_{5}$ \\
\hline DCDA/M & $\mathrm{C}_{3} \mathrm{H}_{6} \mathrm{~N}_{6} / \mathrm{C}_{2} \mathrm{H}_{4} \mathrm{~N}_{4}$ & 210 & 0 & 210 & 140 & $300-400$ & $-0.36 / 0.55$ & 40 & $\mathrm{C}_{3} \mathrm{~N}_{4}$ \\
\hline MPP & $\mathrm{C}_{3} \mathrm{H}_{6} \mathrm{~N}_{6} \cdot \mathrm{HPO}_{3}$ & 206 & 0 & - & - & 410 & 1.00 & 80 & $\mathrm{C}_{3} \mathrm{~N}_{4}{ }^{*} 0.5 \mathrm{P}_{2} \mathrm{O}_{5}$ \\
\hline
\end{tabular}

retardants: Tribromphenylmaleimide $\mathrm{TBrP}$, ethylene bis tetrabromophthalimide $\mathrm{ETBr}$ and the halogene free flame retardants Bicyclopenterythritol phosphate BCPP, equimolar mixture of dicyandiamide and melamine DCDA/M as well as melamine polyphosphate MPP were applied in addition.

In Figure $11 \mathrm{TBrP}$ melted at $142^{\circ} \mathrm{C}$ under heat consumption of $0.05 \mathrm{~kJ} / \mathrm{g}$ and decomposed at $300^{\circ} \mathrm{C}$ with -0.004 and $0.01 \mathrm{~kJ} / \mathrm{g}$ heat of decomposition, $\mathrm{ETBr}$ melted under heat uptake of $0.065 \mathrm{~kJ} / \mathrm{g}$ at $460^{\circ} \mathrm{C}$ followed by exothermic decomposition with -0.05 and $0.04 \mathrm{~kJ} / \mathrm{g}$ heat evolution.

The applied FRs were different in their mechanism of activity. Tribromophenylmaleimide TBrP was integrated into the chain during curing. Ethylene bistetrabromrophthalimide was non reactive. In the case of fire both halogene FRs split off bromine, which interfered with the radical chain of combustion Bicyclopentaerythritole phosphate BCPP was intumescent and built a cellular char under heat. The mixture of dicyandiamide and melamine DCDA/M evolved non burning gases and reacted to melamine $\mathrm{C}_{3} \mathrm{H}_{6} \mathrm{~N}_{6}$ and further to $\mathrm{C}_{3} \mathrm{~N}_{4}$. Under fire Melamine polyphosphate MPP changed to ammonia, water and $\mathrm{C}_{3} \mathrm{~N}_{4}{ }^{*}\left(\mathrm{P}_{2} \mathrm{O}_{5}\right) 0.5$.

In Figure $12 \mathrm{DCDA} / \mathrm{M}$ melted at $210^{\circ} \mathrm{C}$ with $0.14 \mathrm{~kJ} / \mathrm{g}$ heat uptake. At $270^{\circ} \mathrm{C}$ a reaction took place with $0.36 \mathrm{~kJ} / \mathrm{g}$ heat evolution. Decomposition occurred at $320-430^{\circ} \mathrm{C}$ with $0.55 \mathrm{~kJ} / \mathrm{g}$ heat of decomposition. The intumescent FR BCPP showed two exotherm peaks at 310 and $350^{\circ} \mathrm{C}$ with each $-0.1 \mathrm{~kJ} / \mathrm{g}$ evolution of heat. MPP degraded at $410^{\circ} \mathrm{C}$ with of $1.1 \mathrm{~kJ} / \mathrm{g}$ heat of decomposition. The flame retardants bicyclopentaerythritol phosphate $\mathrm{C}_{5} \mathrm{H}_{9} \mathrm{O}_{5} \mathrm{P}$, melamine polyphosphate $\mathrm{C}_{3} \mathrm{H}_{6} \mathrm{~N}_{6} \cdot \mathrm{HPO}_{3}$ and the equimolar

DSC halogen FR

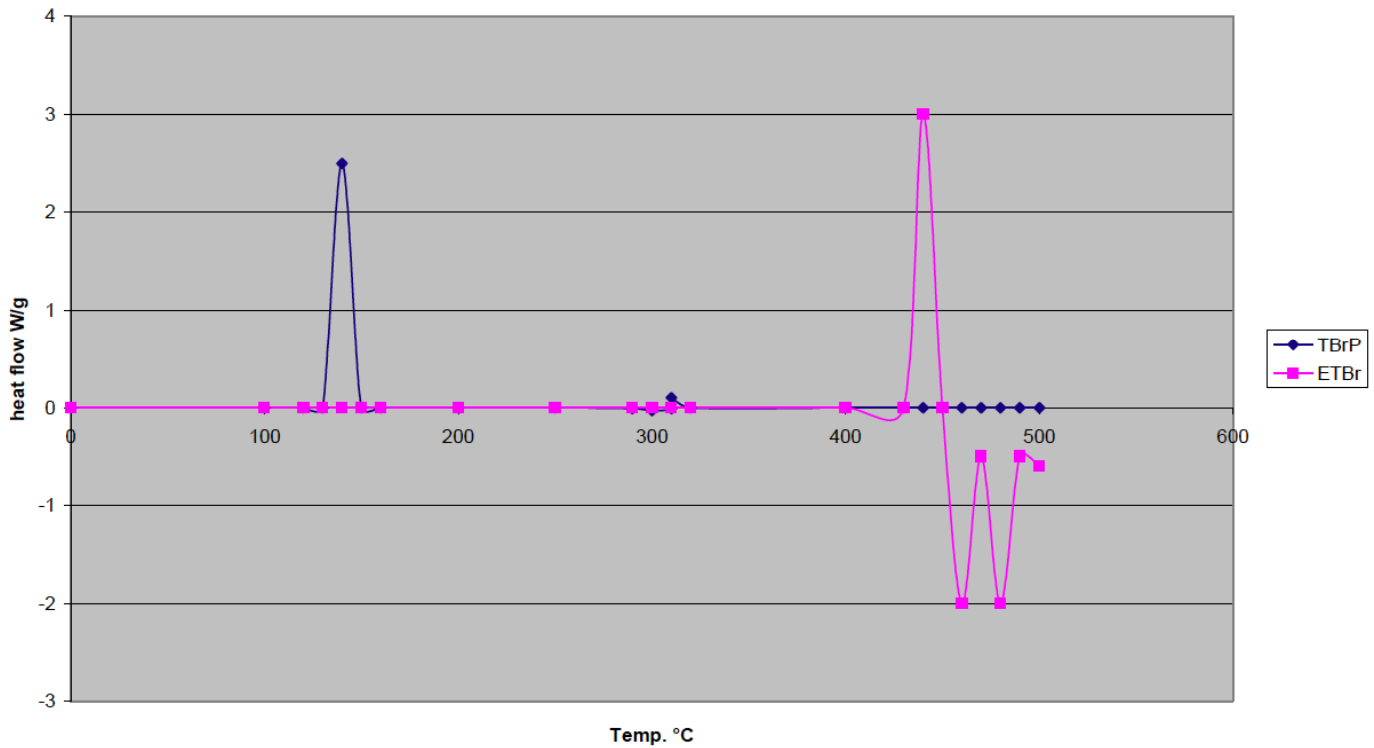

Figure 11: DSC 20K/min $\mathrm{N}_{2}$ of bromine FRs: tribromophenylmaleimide $\mathrm{TBrP} \mathrm{Tf}=140^{\circ} \mathrm{C}, \mathrm{hf}=0.05 \mathrm{~kJ} / \mathrm{g}, \mathrm{Tdec}=300^{\circ} \mathrm{C}, \mathrm{hdec}=-$ $0.006 \mathrm{~kJ} / \mathrm{g}, \mathrm{Tdec}=310^{\circ} \mathrm{C}$, hdec $=0,006 \mathrm{~kJ} / \mathrm{g}$ and ethylene bis tetrabromophthalimide $\mathrm{ETBr} \mathrm{Tf}=445^{\circ} \mathrm{C}, \mathrm{hf}=0.09 \mathrm{~kJ} / \mathrm{g}, \mathrm{Tdec}=460^{\circ} \mathrm{C}$, hdec $=-0.06 \mathrm{~kJ} / \mathrm{g}$, Tdec $=480^{\circ} \mathrm{C}$, hdec $=-0.06 \mathrm{~kJ} / \mathrm{g}$. 
Halogenfree FR

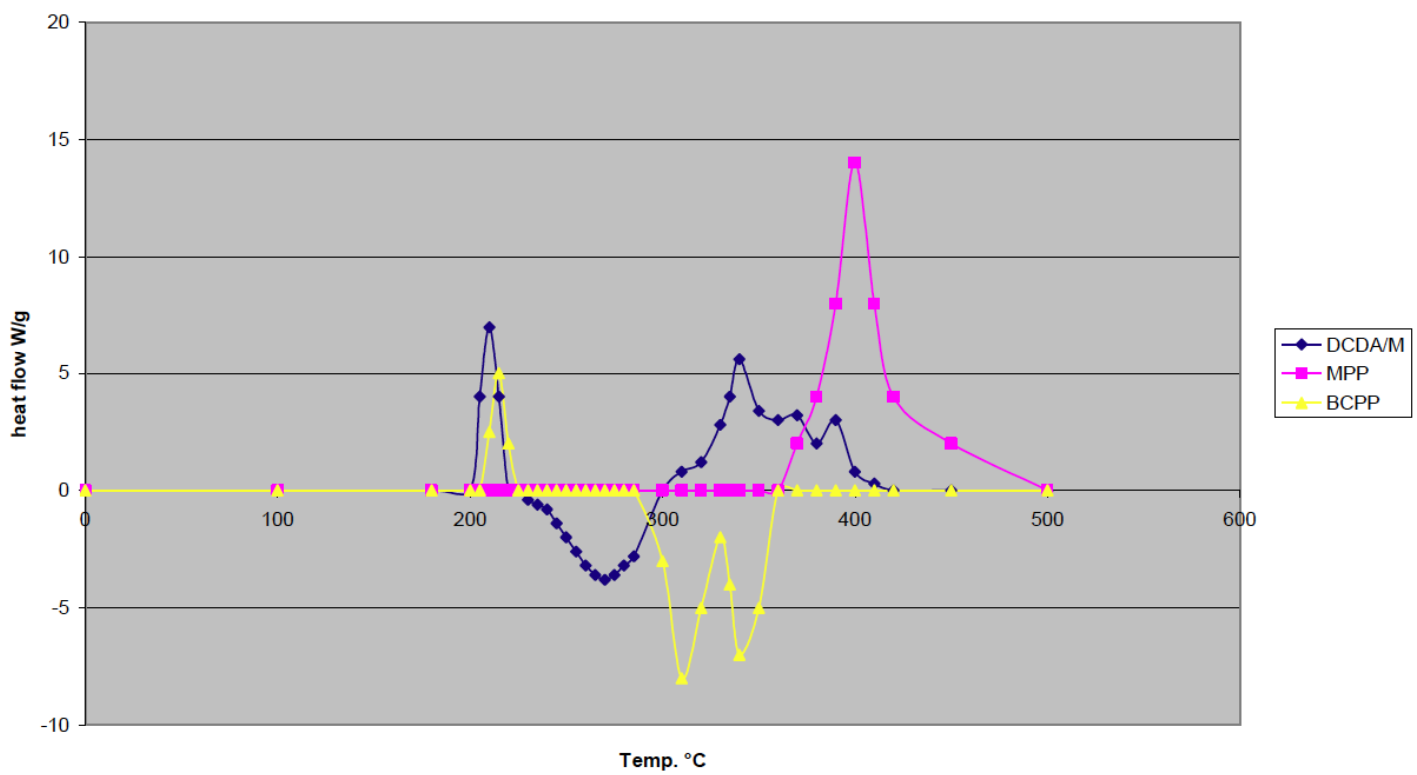

Figure 12: DSC $20 \mathrm{~K} / \mathrm{min}, \mathrm{N}_{2}$ of halogen free FRs: dicyandiamide/melamine $\mathrm{DCDA} / \mathrm{M} \mathrm{Tf}=210^{\circ} \mathrm{C}, \mathrm{hf}=0.14 \mathrm{~kJ} / \mathrm{g}, \mathrm{Treac}=270^{\circ} \mathrm{C}$, hreac $=0.36 \mathrm{~kJ} / \mathrm{g}, \mathrm{Tdec}=300-400^{\circ} \mathrm{C}$, hdec $=0.55 \mathrm{~kJ} / \mathrm{g}$, melamine polyphosphate MPP Tdec $=410^{\circ} \mathrm{C}$, hdec $=1 \mathrm{~kJ} / \mathrm{g}$ and bicylcopentaerythritol phosphate BCPP $\mathrm{Tf}=215^{\circ} \mathrm{C}, \mathrm{hf}=0.12 \mathrm{~kJ} / \mathrm{g}, \mathrm{Tdec}=310^{\circ} \mathrm{C}, \mathrm{hdec}=-0.1 \mathrm{~kJ} / \mathrm{g}, \mathrm{Tdec}=350^{\circ} \mathrm{C}$, hdec $=-0.1 \mathrm{~kJ} / \mathrm{g}$.

mixture of dicyandiamide and melamine $\mathrm{C}_{3} \mathrm{H}_{6} \mathrm{~N}_{6} / \mathrm{C}_{2} \mathrm{H}_{4} \mathrm{~N}_{4}$ degraded to chemically different chars.

16 layers of prepregs were staggered one upon the other in a vacuum press in order to achieve samples with $1.6 \mathrm{~mm}$ thickness for the UL 94 test. The conditions of manufacture were $15 \mathrm{bar}$ pressure, within 30 minutes heating to $180^{\circ} \mathrm{C}$ for 1 hour. The laminates with $1.6 \mathrm{~mm}$ thickness and $45 \%$ resin content were cured at $200^{\circ} \mathrm{C}$ for 48 hours. In the UL94 the after flaming time took 22 seconds for the virgin samples. When 5\% flame retardants were added, the after flaming time was reduced under the necessary limit of 10 seconds.

In Table 15 once more metals, charring and non charring polymers were summarized with their

UL-94 1.6mm specimens

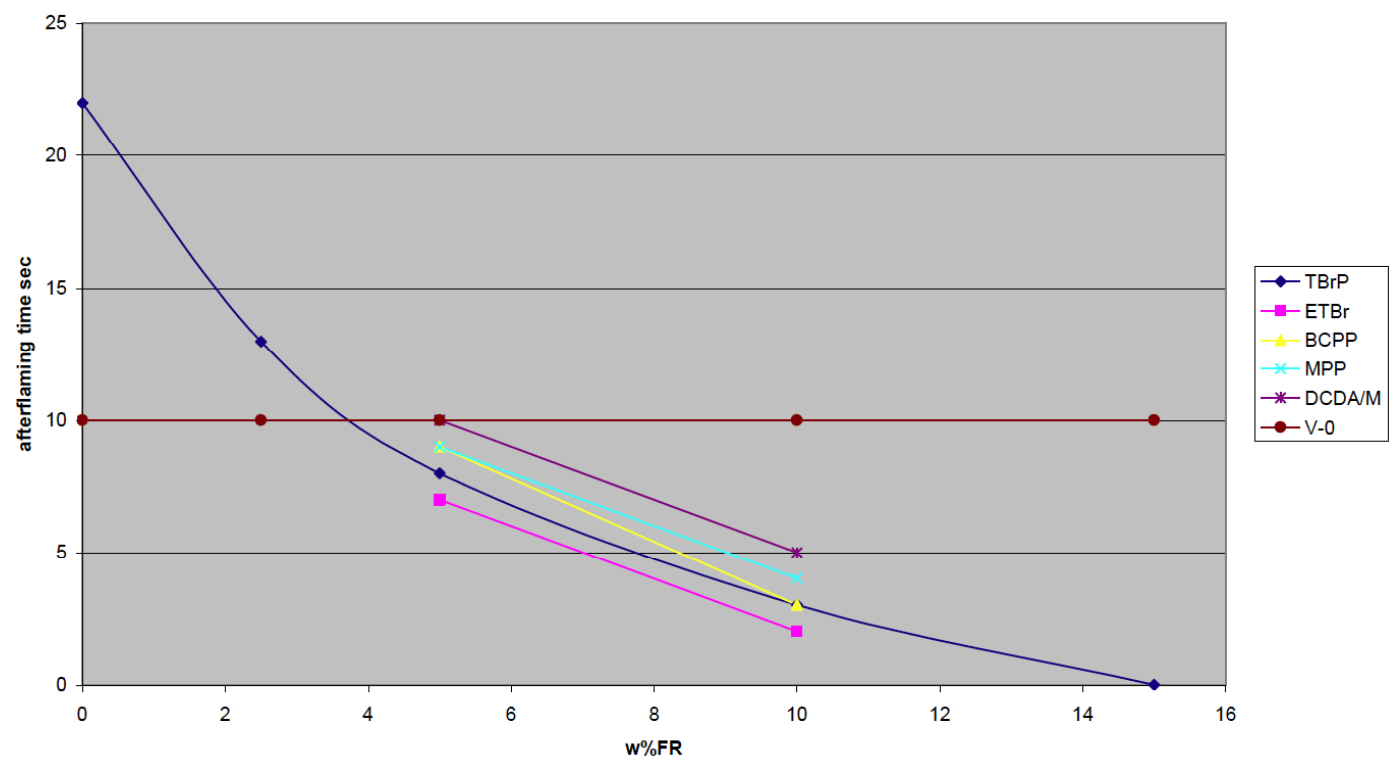

Figure 13: UL94 after flaming time (sec) of BMI (2.5DPBM/1MDA) glass laminates with $45 \%$ resin content and $55 \%$ glass fabric US 2116 (curing $48 \mathrm{~h}$ at $200^{\circ} \mathrm{C}$ ) versus amount of FRs. 
Table 15: Comparison of BMI with Polyimides, Metals, Engineering Plastics and Cellulose and PAN

\begin{tabular}{|c|c|c|c|c|c|c|c|}
\hline Material & $\begin{array}{c}\text { MW } \\
\text { g/mole }\end{array}$ & $\begin{array}{c}\text { Density } \\
\text { g/cm3 }\end{array}$ & $\begin{array}{l}\mathrm{Tf} / \mathrm{Tg} \\
{ }^{\circ} \mathrm{C}\end{array}$ & $\begin{array}{c}\text { Tdec } \\
{ }^{\circ} \mathrm{C}\end{array}$ & $\begin{array}{l}\mathbf{R} \\
\%\end{array}$ & $\begin{array}{l}\text { LOI } \\
\% 02\end{array}$ & $\begin{array}{c}\text { h comb } \\
\mathrm{kJ} / \mathrm{g}\end{array}$ \\
\hline BrPhenyl & 356 & 1.15 & $/ 285$ & 450 & 7 & 60 & -25.1 \\
\hline Phenyl & 227 & 1.10 & $/ 230$ & 460 & 17 & 50 & -32.6 \\
\hline Xylyl & 305 & 1.10 & $/ 280$ & 450 & 20 & 55 & 33.9 \\
\hline 2.5DPBM/1A & 988 & 1.20 & $/ 380$ & 450 & 30 & 35 & -28.1 \\
\hline 2.5DPBM/1MDA & 1093 & 1.25 & $/ 350$ & 470 & 47 & 40 & -29.3 \\
\hline PI Kapton & 382 & 1.27 & & 500 & 50 & 36.5 & -25.0 \\
\hline Matrimid 5218 & 552 & 1.20 & $/ 280$ & 450 & 26 & & -30.8 \\
\hline PSI Techimer & 534 & 1.15 & & 450 & 22 & 33 & -24.4 \\
\hline PAI Torlon & 354 & 1.38 & $/ 280$ & 400 & 50 & 45 & -29.5 \\
\hline PEI Ultem & 593 & 1.27 & $/ 227$ & 450 & 43 & 35 & -29.5 \\
\hline PEstl & 648 & 1.26 & & 450 & 35 & 40 & -27.5 \\
\hline Cellulose & 324 & 1.50 & & 300 & 16 & 19 & -16.1 \\
\hline PAN & 53 & 1.18 & $/ 100$ & 300 & 68 & 18 & $-30,8$ \\
\hline PBI Celazole & 306 & 1.30 & 1425 & 500 & 75 & 41.5 & -32.5 \\
\hline C graphite & 12 & 2,26 & & 800 & 100 & 67 & $-32,8$ \\
\hline $\mathrm{Fe}$ & 56 & 7.86 & 1528 & 500 & 100 & & -14.7 \\
\hline $\mathrm{Al}$ & 27 & 2.70 & 660 & & & & -62.1 \\
\hline PVC & 62.5 & 1.40 & 180 & 300 & 0 & 42 & -17.5 \\
\hline PE & 26 & 0.98 & 135 & 420 & 0 & 18 & -46.3 \\
\hline PS cryst & 104 & 1.08 & 240 & 450 & 0 & 18.5 & -42.0 \\
\hline PA6 & 113 & 1.12 & 220 & 460 & 0 & 25 & -38.7 \\
\hline PA66 & 226 & 1.12 & 260 & 460 & 0 & 23 & -31.8 \\
\hline
\end{tabular}

${ }^{*}$ Iron loses $50 \%$ of its toughness at $500^{\circ} \mathrm{C}$.

densities, temperatures of fusion $\mathrm{Tf}$, glass transition $\mathrm{Tg}$, temperatures of decomposition Tdec, residues R, LOI values and heats of combustion hcomb.

Under the condition of pyrolysis charring polymers like polyimides $\mathrm{PI}$, coPI as well as Polyacrylnitrile PAN and cellulose degraded to carbonaceous residues. In Table 15 PAN with $68 \%$ residue was the polymer with the highest residue followed by $\mathrm{PI}$ and Copolyimides.

Iron possessed the highest density followed by aluminium and graphite whereas plastics were the lightest materials. Polymers with residues, the so called charring polymers, solidified in the glassy state. The ladder polymer PAN and cellulose could be charred to carbon fibres. The burning behaviour was characterized by the LOI value. Graphite showed the highest LOI value. The highest heat of combustion hcomb exerted aluminium.

When only charring polymers without halogen from Table 15 were taken into consideration and their heats of combustion hcomb were put in relation with the inverse LOI value. The data were situated more less on a straight line, which could be described by equation 5 .

hcomb $=37-4 \cdot 1(1 / \mathrm{LOI})$

equ. 5

The non charring polymers obeyed equation 6 known as Johnson equation.

hcomb $=8^{*}(1 /$ LOI $)$

equ. 6

Equation 5 described the situation that charring polymers accumulated more and more carbon approaching graphite with high heat of combustion and low burning.

\section{CONCLUSIONS}

In Table 16 and 16a commercial thermoplastic polyimides, polybenzimidazoles as representatives of heat resistant polymers and polyamide 66 as a representative of engineering plastics are summarized. The thermodynamic approach allows the determination 
h comb versus $1 /$ LOI

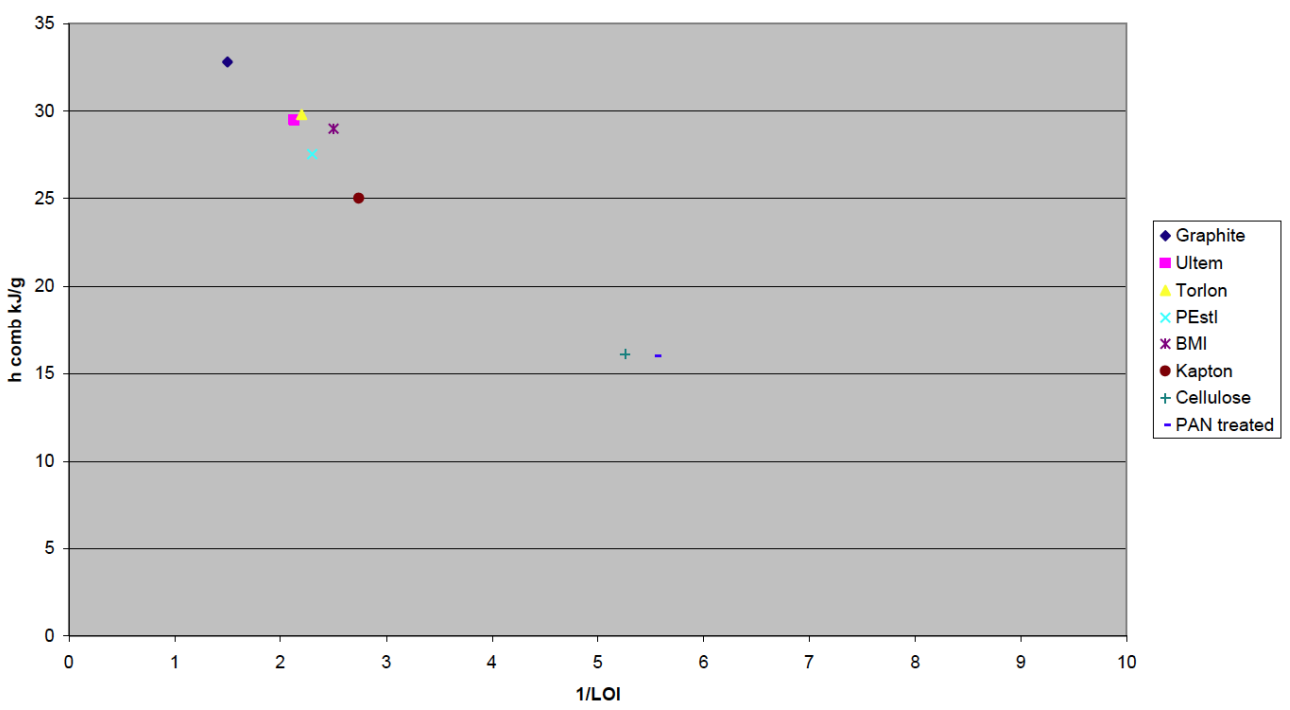

Figure 14: Charring polymers with their heats of combustion $\mathrm{hcomb} \mathrm{kJ} / \mathrm{g}$ and $\mathrm{LOI}$ values.

Table 16: Thermoplastic PI, Polybenzimidazol and Copolyimides

\begin{tabular}{|c|c|c|c|c|c|}
\hline Product & PI & PBI & PAI & PEI & PSI \\
\hline Brand & Matrimid 5218 & Celazole & Torlon & Ultem & Techimer \\
\hline Company & Ciba Geigy & Hoechst Cel. & Amoco & G.E. & Techimer \\
\hline MW g/mole & 552 & 308 & 354 & 593 & 534 \\
\hline $\mathrm{Hf} \mathrm{kJ/mole}$ & -457 & 419 & -217 & $-625,5$ & -660.5 \\
\hline hcomb kJ/g & -30.3 & -32.5 & -29.5 & -29.5 & -24.4 \\
\hline $\operatorname{Tdec}{ }^{\circ} \mathrm{C}$ & 400 & 450 & 400 & 400 & 400 \\
\hline Hdec kJ/g & 0.51 & -1.95 & -0.20 & -0.13 & 0.19 \\
\hline Rdec $\%$ & 30 & 75 & 41 & 45 & 22 \\
\hline
\end{tabular}

Table 16a:

\begin{tabular}{|c|c|c|c|c|}
\hline Product & PEstl & PSI S269 & PA66 & Br.Phenyl \\
\hline \hline Brand & experimental & experimental & DurethaneA31 & experimental \\
\hline Company & Chemie Linz & Chemie Linz & Bayer & $\mathrm{C}_{18} \mathrm{H}_{14} \mathrm{NO}_{2} \mathrm{NBr}$ \\
\hline Formula & $\mathrm{C}_{39} \mathrm{H}_{24} \mathrm{~N}_{2} \mathrm{O}_{8}$ & $\mathrm{C}_{45} \mathrm{H}_{22} \mathrm{~N}_{2} \mathrm{O}_{7} \mathrm{~S}_{3}$ & $\mathrm{C}_{12} \mathrm{H}_{22} \mathrm{~N}_{2} \mathrm{O}_{2}$ & 356 \\
\hline $\mathrm{MW}(\mathrm{g} / \mathrm{Mole})$ & 648 & 798 & 226 & -167 \\
\hline $\mathrm{Hf}(\mathrm{kJ} / \mathrm{mole}$ & $-943,5$ & $-599,5$ & -650 & 0.0015 \\
\hline $\mathrm{hg} / \mathrm{hm} \mathrm{kJ/g}$ & & & 10.070 & 1285 \\
\hline $\mathrm{Tm} / \mathrm{Tg}{ }^{\circ} \mathrm{C}$ & $/ 250$ & $/ 270$ & $269 /$ & -25.1 \\
\hline $\mathrm{hcomb} \mathrm{kJ/g}$ & -27.5 & $-27,3$ & $-32,8$ & 450 \\
\hline $\mathrm{Tdec}{ }^{\circ} \mathrm{C}$ & 400 & 400 & 460 & 1.43 \\
\hline $\mathrm{hdec} \mathrm{kJ/g}$ & -0.49 & -0.07 & $-0,65$ & 7 \\
\hline $\mathrm{Rdec} \%$ & 35 & 8 & 0 & \\
\hline $\mathrm{Lit.}$ & {$[43,52-54]$} & {$[40,41]$} & & \\
\hline
\end{tabular}


Table 17: Thermoset BMls, Kapton and PI

\begin{tabular}{|c|c|c|c|c|}
\hline Product & Kapton & PI & MDA & A \\
\hline Brand & Vespel & experimental & experimental & experimental \\
\hline MWg/nole & 382 & 486 & 1093 & 988 \\
\hline $\mathrm{Hf} \mathrm{kJ/mole}$ & -517 & -581 & -1326 & -1404 \\
\hline hcomb kJ/g & -24.6 & -26.4 & -29.0 & -28.1 \\
\hline $\operatorname{Tdec}^{\circ} \mathrm{C}$ & 550 & 450 & 470 & 450 \\
\hline hdec kJ/g & -0.07 & -0.10 & 0.45 & 0.35 \\
\hline Rdec \% & 40 & 30 & 49 & 30 \\
\hline
\end{tabular}

of volatile products and of the amount of heat produced during degradation. PA 66 is a non charring polymer Rdec $=0 \%$, polyimides and polybenzimidazoles are charring polymers, which degrade to residues Rdec $>0 \%$. The polyimides as well as polybenzimidazole $\mathrm{PBI}$ exert exotherm heats of decomposition hdec. High heat resistance and easy workability are contradicting and have to be balanced in each case. PBI shows improved heat resistance but is difficult to handle. The thermoplastic copolyimides PAI, PEI, PEstl and PSI as well 2Bromphenylmaleimide styrene copolymer reach glass temperatures about $10^{\circ} \mathrm{C}$ higher than $269^{\circ} \mathrm{C}$ the melting temperature of polyamide 66 . The quantitative treatment of the glass transition temperature determines the enthalpy of glass transition hg about $0.5-1.1 \mathrm{~J} / \mathrm{g}$, which is small in comparison with the enthalpy of melting hm about $70-300 \mathrm{~J} / \mathrm{g}$. Nevertheless the small differences in the calculated enthalpies and entropies indicate that high values of enthalpy due to intermolecular interactions and low values of entropy caused by steric hindrance lead to high Tg. According to Table 16 and 16a thermoplasts with glass temperatures in the range of 210 to $280^{\circ} \mathrm{C}$ degrade at temperatures of 400 to $460^{\circ} \mathrm{C}$. Their properties have to be compared with those of thermosets in Table 17.

Thermosets exert higher glass temperatures of 300 to $700^{\circ} \mathrm{C}$ and degrade between 550 and $450^{\circ} \mathrm{C}$. Resins based on $2.5 \mathrm{mDPBM} / 1 \mathrm{mMDA}$ and $2.5 \mathrm{~m}$ DPBM $/ 1 \mathrm{~mA}$ belong to thermosets like Kapton or Vespel and $\mathrm{PI}$, which comprises benzophenone dianhydride and bis aniline ether. In comparison with thermoplastics all thermosets have the advantage of low processing temperatures but the disadvantage of time consuming curing and processing risks like bubble formation and varying physical properties. PolyDPBM has a high $\mathrm{Tg}$ of $435^{\circ} \mathrm{C}$ and a high Tdec of $475^{\circ} \mathrm{C}$ but the energy of fracture is too low for practical application. DPBM and BMls polymerize to linear polymers with imide bonds situated in the side chains. Therefore strictly spoken they are no polyimides, which carry their imide linkages in the main chains. In order to liberate BMIs from their niche existence, cost reduction is needed. A switch from $2.5 \mathrm{mDPBM} / 1 \mathrm{mMDA}$ to $2.5 \mathrm{mDPBM} / 1 \mathrm{~mA}$ has cost reduction as consequence. As both substances are similar in toxicity their monomer content has to be very low. MDA is under the suspicion of causing cancer and $A$ is a poison for blood, their amounts have to be as small as possible. The absence of free amine is achieved by precipitating the reaction mixture in MSA acidic water. In the unsolved state the equilibrium between bounded and free amine is no longer valid. The water soluble amine-maleic acid salt can be washed out completely. The process of manufacture is optimized, when the addition product (DPBM)MDA is synthesized from the reactants MDA and maleic anhydride MSA in an one pot reaction without isolating DPBM. The precursor resin 2.5DPBM)1MDA has a glass temperature of $335^{\circ} \mathrm{C}$, a temperature of degradation of $470^{\circ} \mathrm{C}$ and a energy of fracture of $100 \mathrm{~J} / \mathrm{m}^{2}$. The precursor resin $\left.2.5 \mathrm{DPBM}\right) / 1 \mathrm{~A}$ has a glass transition temperature of $380^{\circ} \mathrm{C}$, a temperature of degradation of $430^{\circ} \mathrm{C}$ and an energy of fracture of $75 \mathrm{~J} / \mathrm{m}^{2}$. As the reaction of DPBM with styrene to a soluble resin fails, 2- Bromophenylmaleimide and 
styrene are applied on tissues for the production of prepregs. After curing a glass transition temperature of $285^{\circ} \mathrm{C}$ is obtained. Flame retardants reduce the after flaming time and shift the weight loss curve from that under air to that under nitrogen. The flame retardants though very different in mechanism exert similar efficiency, an amount of $5 \%$ is sufficient to reach after flaming times below 10 seconds for a V-0 classification. BMls belong to the group of charring polymers, for which a correlation between the heat of combustion and the inverse limiting oxygen index is obtained, quite opposite to that valid for non charring polymers. The correlation predicts that polymers with high heats of combustion are low burning. The quantitative treatment of the glass transition temperature showed that the enthalpy of glass transition is much smaller than the enthalpy of melting. Nevertheless the data indicate that high glass temperatures are combined with high enthalpies due to intermolecular bonding and low entropies caused by steric hindrance.

\section{NOMENCLATURE}

$$
\begin{array}{ll}
\mathrm{EA} & =\text { energy of activation } \mathrm{kJ} / \mathrm{mole} \\
\mathrm{hcomb} & =\text { heat of combustion } \mathrm{kJ} / \mathrm{g} \\
\mathrm{hdec} & =\text { heat of decomposition } \mathrm{kJ} / \mathrm{g} \\
\mathrm{Hf} & =\text { Heat of formation } \mathrm{kJ} / \mathrm{mole} \\
\mathrm{Hg} & =\text { heat of glass transition } \mathrm{kJ} / \mathrm{mole} \\
\mathrm{hm} & =\text { heat of melting } \mathrm{kJ} / \mathrm{g} \\
\mathrm{hpol} & =\text { heat of polymerization } \mathrm{kJ} / \mathrm{g} \\
\mathrm{LOI} & =\text { limiting oxygen index } \\
\mathrm{MW} & =\text { molecular weight } \mathrm{g} / \mathrm{mole} \\
\mathrm{Sg} & =\text { entropy of glass transition } \mathrm{J} /\left(\mathrm{mole}^{*} \mathrm{~K}\right) \\
\mathrm{Tg} & =\text { glass transition temperature }{ }^{\circ} \mathrm{C} \\
\mathrm{Tm} & =\text { melting temperature }{ }^{\circ} \mathrm{C}
\end{array}
$$

\section{REFERENCES}

[1] Othmer K. Polyimides. Encyclopedia of Chemical Technology $3^{\text {rd }}$ ed. John Wiley and Sons/ New York 1982; Vol.18: pp. 704-719.

[2] Othmer K. Polyimides. Encyclopedia of Chemical Technology $4^{\text {th }}$ ed. A. Wiley International Publ. New York 1996; Vol. 19: pp. 829- 834

[3] Othmer K. Composite Materials. Encyclopedia of Chemical Technology $4^{\text {th }}$ ed. A. Wiley Interscience. New York 1993; Vol. 7: 40-60.
Othmer K. Phosphorus-containing Polymers. Encyclopedia of Chemical Technology $3^{\text {rd }}$ ed. John Wiley and Sons/New York 1987; Vol. 11: 101-102.

[5] Polyimides. Ullmann's Encyclopedia of Industrial Chemistry. VCH Publishing Inc. 1992; Vol. A21: 253-268.

[6] Mark, Bikales, Overberg, Menges. Encyclopedia of Polymer Science and Engineering $2^{\text {nd }}$ ed. John Wiley and Sons, New York 1988; p. 364

[7] The Encyclopedia of Advanced Materials, Bloor D, Brook RJ, Flemings MC, Mahajan S, ed. Performance Polymers. Pergamon Press Monomers for High 1993; pp. 1692-1700.

[8] Mittal KL. Polyimide and Other High Temperature Polymers, Synthesis, Characterization and Application. Kindle Edition 2009; Vol. 5. https://doi.org/10.1163/ej.9789004170803.i-424

[9] Stenzenberger H. Constituent Materials. Bisimide Resins 2001; pp. 97-104. https://doi.org/10.31399/asm.hb.v21.a0003364

[10] Der-Jang L, Kung-Li W, Ying-Chi H, Kueir-Ram L, Juin-Yih L, Chang-Sik H. Advanced polyimide materials: Synthesis, physical properties and applications. Progress in Polymer Science 2012; 37(7): 907- 974. https://doi.org/10.1016/j.progpolymsci.2012.02.005

[11] Wilson D, Stenzenberger HD. Polyimide. Taschenbuch Prime 2013.

[12] Behr E. Hochtemperaturbeständige Kunststoffe. Carl Hanser Verlag Munich 1969.

[13] Conley RT. ed. Thermal Stability of Polymers. M. Dekker, New York 1970.

[14] Madorsky SL, Straus S. High Temperature Resistance and Thermal Degradation of Polymers S.C.I Monograph 1961; 13: $60-7414$.

[15] Huang F, Huang F, Zhou Y, Du L. Preparation and properties of bismaleimide resins modified with hydrogen silsesquioxane and dipropargylether and their composites. Polymer Journal 2010; 42: 261-267.

https://doi.org/10.1038/pj.2009.335

[16] Rattam V. Polyimides Chemistry \& Structure. Property relationship. Literature review Modern Plastics mid. Oct. Encyclopedia Issue Polyimide. Thermoset 1999; 146.

[17] Daman, Global Bismaleimide Market by manufacturers, Regions, Type and Application, Forcast to 2021 (2017), damandeep.k.@absolutereports.com.

[18] Fink JK. High Performance Polymers 2nd ed. Elsevier Inc., Amsterdam 2014. https://doi.org/10.1016/B978-0-323-31222-6.00009-1

[19] Elias HG. Neue polymere Werkstoffe. Carl Hanser Verlag/München 1975.

[20] Elias HG. Kunststoffe mit besonderen Eigenschaften, Ullmann 4.Aufl. Bd.15 1979.

[21] Iredale RJ, Ward C, Hamerton I. Modern advances in bismaleimide resin technology: A $21^{\text {st }}$ century perspective on the chemistry of addition polyimides. Progress in Polymer Sci 2017; 69: 1-21.

https://doi.org/10.1016/j.progpolymsci.2016.12.002

[22] Miracle DB, Donaldson StL. ed. ASM Handbook Composites Bismaleimide Resin 2001; Vol. 21: pp. 97-104. https://doi.org/10.31399/asm.hb.v21.a0003364

[23] US 2,818,405. DuPont Kovacic P. Elastomeric reaction products of bismaleimides with organic diamines 1957.

[24] US 3,380,964. Rhone Poulenc Rhodiaceto, Grundschober F., Sameth J., Reticulated polyimides and method of producing some from N.N' bismimides 1968.

[25] Brit 1,190,718. Rhone Poulenc Bargain M., Combert A., New cross-linked Resin 1968

[26] US 4,100,140. Ciba Geigy Zalur Abdul-Cader, Renner A. Process for the manufacture of crosslinked polymers, which contain imide groups 1978 
[27] WO 97/33933. A1 HOS Technik Horacek H. Sulzer P., Bismaleinimidharze mit einem Gehalt an freiem aromatischem Diamin von weniger als 0,1\% 1997.

[28] EP 0330020 A-1. Chemie Linz,Horacek H. Diamines and Bismaleimides as well as Polyimides prepared therefrom 1989.

[29] Metzger JV. Chemistry of Heterocyclic Compounds John Wiley /New York 815 Thiazole and its derivates 1979; 34(1). https://doi.org/10.1002/9780470187067

[30] Müller Houben- Weyl Methoden der organischen Chemie Band IX (1955) G. Thieme/Stuttgart 93 and Band XI/1 1957; 341.

[31] Varma IK, Sanita S, Varma DS. Addition Polyimides: III. Thermal Behavior of Bismaleimides. J Polym Sci Pol Chem Ed. 1984; 22: 1419-1433. https://doi.org/10.1002/pol.1984.170220622

[32] US 4,433,115. NASA, I.K. Varma, G.M.Fohlen, Phosphorus Containing imide resins 1984.

https://doi.org/10.1007/978-1-4615-6743-1_8

[33] Varma IK, Fohler GM, Parker JA. Addition polyimides III: Thermal behaviour of bismaleimides, Synthesis of N,N 3,3 maleimidophenylsulfone and its Michael addition product with 44 'aminodiphenylmethane. J Macromolecular Sci Chem Part A 1983; 209-223.

[34] Farr IV, Grass TE, Ji Q, Granth JE. Synthesis and characterization of diaminophenyl indane based polyimides via ester acid solution imidization. High Performance Pol Vol 1997; 9: 345-352.

https://doi.org/10.1088/0954-0083/9/3/012

[35] AT 388914. Chemie Holding AG. Greber G, Gruber H, Sychra M, Preparation of bis[(aroylamino)phenyl] diphenylsulfones as monomers for thermostable polymers 1989.

[36] EP 316775 A-1. Chemie Linz, Horacek H, Greber G, Bismaleimide sowie daraus hergestellte Polyimide 1987.

[37] WO 89/04298. Chemie Linz Holding, Greber G. Gruber H. Sychra M., Sulfur containing aromatic Tetracarboxylic acids and their derivatives 1980 .

[38] US 3,127,414. DuPont Cole Halbert, Gruber Wilhelm, Preparation of $\mathrm{m}$-phenylenedimaleimide 1964.

[39] WO 97/47597. HOS Technik Horacek H. Steinbauer G., Process for Preparation of twice unsaturated Bisimides with a high level of colour stability and a low level of polymers 1997.

[40] Haas HC, MacDonald RL. Maleimide polymers: A colour reaction. J Pol Sci Polym Chem 2003; 11(2): 327-334. https://doi.org/10.1002/pol.1973.170110202

[41] Beilstein, Addition of aniline to N-Phenylmaleimide via Michael addition. Handbook of Organic Chemistry Vol. XXII p.529; E V 21/10 p.11 Roy. Swan J Chem Soc 1969; 18861889.

[42] van Krevelen DW. Properties of Polymers Correlation with Chemical Structure, Elsevier Publ. Corp. Amsterdam 1972.

[43] van Krevelen DW. Properties of Polymers, Elsevier Publ. Corp. Amsterdam. Thermal decomposition 1990; Chapter 21, 463

[44] Xiong Y, Boey FYC, Rath SK. Kinetic study of the curing behaviour of Bismaleimide Modified with Diallylbisphenol A. J
Appl Pol Sci 2003; 90(8): 2229-2240.

https://doi.org/10.1002/app.12885

[45] Radue MS, Varshney V, Baur JW, Roy AK, Odegard GM Molecular Modelling of Cross linked Polymers with Complex Cure Pathways: A Case study of Bismaleimide Resin. Macromolecules 2018; 51(5): 1830-1840. https://doi.org/10.1021/acs.macromol.7b01979

[46] Vollmert B. Grundriß der makromolekularen Chemie. Springer Verlag 1962; 32. https://doi.org/10.1007/978-3-662-25680-0

[47] Giulio CD, Gautier M, Jasse B. Fourier Transform Infrared Spectroscopic Characterization of Aromatic Bismaleimide Resin in Cure States. J Appl Polym Sci 1964; 29: 1771-1779. https://doi.org/10.1002/app.1984.070290530

[48] Grenier-Loustalot MF, Gouarderes F, Joubert F, Grenier Ph Synthesis, mechanism and kinetic of radical polymerization of bismaleimidetype telechelic oligomers in solvent and in solid state. Polymer 1993; 34(18): 3848-3859. https://doi.org/10.1016/0032-3861(93)90510-H

[49] Barton JM, Hamerton I, Rose JB, Warner D. The synthesis, characterization and polymerization kinetic study of a series of related addition polyimides. High Perform Polym 1994; 6 : 21-34.

https://doi.org/10.1088/0954-0083/6/1/003

[50] Grenier-Loustalot MF, da Cunha L. Thermostabile polymers: Spectroscopic and thermal studies of bismaleimides systems in solid state. High Perform Polym 1998; 10: 285-308. https://doi.org/10.1088/0954-0083/10/3/006

[51] Phelan JC, Sung CSP. Cure Characterization in Bismaleimide Diallylbisphenol A Resin by Fluorescence FT IR nd UV Reflection Spectroscopy. Macromolecules 1997; 30(22): 6845-6851. https://doi.org/10.1021/ma961887f

[52] Li J, Stoliarov Stl. Measurement of kinetics and thermodynamics of thermal degradation for charring polymers. Polym Degrad Stab 2013; 1-14.

\section{https://doi.org/10.1016/j.polymdegradstab.2015.03.003}

[53] Li J, Gong J, Stoliarov Stl. Development of Pyrolysis Models for charring Polymers. Polym Degrad and Stab 2015; 115 138-152.

[54] Austen AC, Sivarajan S. Encyclopdia of Materials Science and Technology (2004); Reference Moule in Material Science and Material Engineering. Glass Transition 2017.

[55] Ojovan MI, Travis KP, Hand RJ. Condensed Thermodynamic parameters of bonds in glassy materials from viscosity temperature relationship. J Physics 2007. https://doi.org/10.1088/0953-8984/19/41/415107

[56] Loncrini DF. Aromatic Polyesterimides. J Pol Sci Part A-1 1988; 1: 1331-1541.

[57] EP 0597301 A-1. Chemie Linz, Horacek H., Polyesterimide aus Trimellitsäure, Propandiphenol und einem aromatischen Diaminen mit verbesserten Eigenschaften, ihre Herstellung und Verwendung 1994.

[58] Dolui SK, Pal D, Maiti S. Synthesis of a Novel Polyesterimide. J Appl Pol Sci 1985; 30: 3867-3878. https://doi.org/10.1002/app.1985.070300925

\section{DOI: https://doi.org/10.6000/1929-5995.2020.09.01}

(c) 2020 Heinrich Horacek; Licensee Lifescience Global.

This is an open access article licensed under the terms of the Creative Commons Attribution Non-Commercial License (http://creativecommons.org/licenses/by-nc/3.0/) which permits unrestricted, non-commercial use, distribution and reproduction in any medium, provided the work is properly cited. 